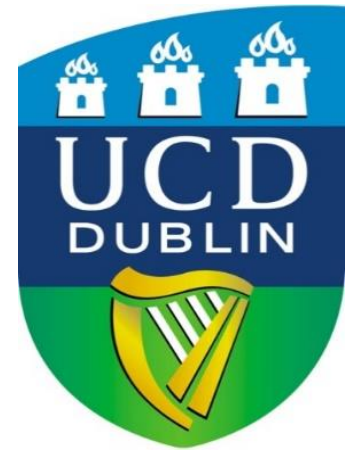

UCD GEARY INSTITUTE FOR PUBLIC POLICY

DISCUSSION PAPER SERIES

\title{
Which Wheel Gets the Grease? \\ Constituent Agency and Sub-national World Bank Aid Allocation
}

\author{
Samuel Brazys \\ School of Politics \& International Relations \\ University College Dublin \\ Krishna Chaitanya Vadlamannati \\ School of Politics \& International Relations \\ University College Dublin \\ Tianyang Song \\ School of Politics \& International Relations \\ University College Dublin
}

Geary WP2019/07

April 9, 2019

UCD Geary Institute Discussion Papers often represent preliminary work and are circulated to encourage discussion. Citation of such a paper should account for its provisional character. A revised version may be available directly from the author. 


\begin{abstract}
Questions of aid allocation have long focused on discerning the altruistic, self-interested or meritocratic motivation of development donors. Less attention has been paid to the interests and agency of recipient state governments and even less to the interests and agency of constituencies within those states. An implicit assumption is often that the "poor" either passively receive the patronage of their benefactors or they don't. In this paper, we instead suggest that depending on the altruism/egoism of a donor, their sensitivity to needy subnational constituencies in aid allocation also depends on the political empowerment of those groups. In particular, we take advantage of the unique socio-cultural structure in India to examine if the political agency of scheduled castes and tribes (SC/STs) can explain patterns of district-level allocation of World Bank education aid. Using district-level data on a multi-year World Bank education program, district-level proportions of SC/STs and SC/ST population and of members of parliament, we find that SC/ST districts receive more aid, even when controlling for baseline poverty and educational performance. These results are especially strong when these districts are politically empowered. Our findings suggest that while donors may indeed respond to recipient needs, those recipients who also speak loudly for themselves fare better, highlighting the importance of constituent agency.
\end{abstract}




\section{Introduction}

How and why foreign aid is allocated has been the subject of a vast literature spanning decades of research. The historical distinctions have been between "recipients' needs", "recipients' merit", and "donors' interests" with a focus on understanding differences in cross-national allocation patterns. ${ }^{1}$ Recent work has seen more nuanced theoretical development, ${ }^{2}$ but also a move to understanding sub-national allocation patterns. ${ }^{3}$ However, this work has still produced inconsistent findings, with some scholars finding pro-poor focus in allocation and others not. Beyond this, this literature has almost exclusively focused on the supply side of foreign aid allocation - the motivations, tactics or methods of donors and/or their governmental or non-governmental agents. Less attention has been paid to the demand side of foreign aid allocation - if, how and why the ultimate aid beneficiaries are able to effectively influence their own aid allocation.

This paper proposes that if donors are sufficiently altruistic in their motivations, they will allocate aid to needy constituencies especially when those constituencies are politically empowered. Politically empowered development constituencies can serve to crystalize demand and reduce search costs but can also deliver both input and output legitimacy to donors. Additionally, they can credibly challenge donors with an ex post reputational cost of neglecting the constituency. Vocal constituencies who are not served by aid distributions can make the "failings" of donor institutions known to their stakeholders and broader publics.

To examine these dynamics, we focus on the allocation of the World Bank's District Primary Education Project (DPEP) in India from 1994 to 2001. Due to its organizational structure of multiple and collective principals, scholars have long argued that international organizations (IOs) may have sufficient "independence" or "agency slack" that can render space for altruistic behavior. This makes the World Bank a useful donor for examining our theoretical propositions. Likewise, focusing on India allows us to avail of the country's salient socio-cultural class structure and officially designated scheduled castes and schedules tribes (SC/STs). These societal distinctions enable us to introduce a crucial distinction into our analyses by letting us separate political constituencies within the broader and more general "poor". Moreover, as the country with largest absolute numbers of impoverished citizens in the world, India is also the

\footnotetext{
${ }^{1}$ McKinlay and Little 1978.

2 Bermeo 2017.

${ }^{3}$ Briggs 2014, 2017; Jablonski 2014; Nunnenkamp, Öhler and Andrés 2017.

${ }^{4}$ Abbott and Snidal 1998; Nielson and Tierney 2003.
} 
largest recipient of aid from the World Bank and the distribution of that aid has varied widely across India's expansive geography, allowing for reasonable identification of subnational allocation patterns.

Our focus on the education sector also yields benefits for our analysis. As education aid is unlikely to have any immediate geo-strategic or economic payoff, it is a most likely sector for altruistic allocation, especially to the extent that universal education has been billed as a human right. ${ }^{5}$ The safeguarding of the education rights of minorities is not only associated with human capacity and freedom, ${ }^{6}$ but also promoted as an efficient way to eliminate poverty. ${ }^{7}$ Likewise, unlike economic infrastructure or, indeed, even commercial ventures, there are few, if any, a priori constraints on the geographic allocation of education aid. These features allow for an unfiltered analysis of the relationship we propose.

In the following sections, the paper first develops a theoretical framework of sub-national aid allocation that depends on the altruism of the donor actor, the interests of recipient governments, and the political empowerment of the (potential) recipient constituencies. The paper then briefly outlines India's education sector development and the World Bank's role therein before turning to an analysis of World Bank education programs across 593 districts which considers measures of district-level poverty, the proportion of scheduled caste/scheduled tribe (SC/ST) population and the SC/ST status of members of parliament. The analysis finds that districts with increased SC populations do receive more World Bank education aid beyond that expected to generally "poor" districts, but that that the allocation is magnified substantially when a district also had a SC/ST member of parliament in government. We then conclude with broader thoughts about the importance of incorporating recipient constituency agency when considering allocation patterns of development assistance.

\section{Constituency Agency and Subnational Aid Allocation: Theoretical Foundations}

When discussing determinants of aid allocation from donors, scholars normally concentrate on two concepts, motivation and strategy. The debate on motivation seeks to disentangle the balance of egoism and altruism in aid allocation. $^{8}$ Discussions on allocation strategy consider what delivery tactics

\footnotetext{
${ }^{5}$ Nussbaum 2011, 20; United Nations 1998.

${ }^{6}$ Sen 1999, 17.

${ }^{7}$ Cremin and Nakabugo 2012.

${ }^{8}$ Berthélemy 2006; Younas 2008; Claessens, Cassimon and Campenhout 2009; Hoeffler and Outram 2011; Brazys 2013; Rahman and Giessen 2017.
} 
donors can use to efficiently promote aid allocation in recipients. ${ }^{9}$ Beyond this, the vast bulk of the aid allocation literature has focused on country-level decision making. This literature focuses almost exclusively on supply-side motivations, recipient countries' needs and/or strategic importance are taken as self-evident to potential donors. The few exceptions consider demands and/or interactions with recipient state governments - who are largely presented as unitary actors. ${ }^{10}$

Only recently has scholarship turned to examining subnational aid allocation patterns. These studies have concentrated on if aid goes to poorer and more vulnerable places, ${ }^{11}$ regions with unique political preferences, ${ }^{12}$ political violence, ${ }^{13}$ places with greater infrastructure where foreign direct investors can benefit more or places where recipients have good implementation ability. ${ }^{14}$ Notably, Briggs finds no evidence that the World Bank or African Development Bank target their aid to the poorest regions of recipient countries. ${ }^{15}$ Briggs' $^{\prime}$ theoretical discussion rests largely on issues of aid bargaining and donor control, suggesting that if aid doesn't flow to the poorest regions this is evidence that donors have lost control to recipient's domestic political economy considerations. ${ }^{16}$ Similarly, Nunnemkamp et al. explore the allocation of World Bank projects in India, disaggregating their analysis by sector. In addition to considering sub-national need, they also entertain the "merit" of sub-national administration. ${ }^{17}$ Like Briggs they consider how local political economy may influence patterns of sub-national allocation. ${ }^{18}$ While Nunnemkamp et al. find little overall evidence of needs-based allocation, they do find evidence of sectorspecific targeting, specifically in the health, water/sanitation and transportation sectors. ${ }^{19}$ However, these studies, like the country-level literature above, still focus largely on supply-side dynamics. To the extent recipient political economy is considered, it is as an either/or - donors either have control or they lose it to the black box of local political considerations. In contrast, Swedlund presents a more nuanced idea that the aid allocation and delivery processes represent a carefully choreographed "development dance" ${ }^{20}$ Rather than an all-or nothing logic, Swedlund's work is suggestive that subnational allocation outcomes are

\footnotetext{
${ }^{9}$ Dietrich 2013; Carter 2014; Dietrich and Wright 2015; Bermeo 2017.

${ }^{10}$ Swedlund, 2017a; $2017 \mathrm{~b}$.

${ }^{11}$ Barrett 2015; Briggs 2017.

${ }^{12}$ Briggs 2014; Albertus 2015.

${ }^{13}$ Bezerra and Braithwaite 2016.

${ }^{14}$ Reinhardt 2006; Nunnenkamp, Öhler and Andrés 2016; Marty, Dolan, Leu and Runfola 2016.

${ }^{15}$ Briggs 2017.

${ }^{16}$ Briggs 2014; Jablonski 2014; Abdulai and Hulme 2015.

${ }^{17}$ Nunnenkamp, Öhler and Andrés 2016.

${ }^{18}$ Briggs 2017.

${ }^{19}$ Nunnenkamp, Öhler and Andrés 2017.

${ }^{20}$ Swedlund 2017a.
} 
ultimately the result of a compromise donor and recipient interests. ${ }^{21}$ Yet even here, Swendlund focuses primarily on donor interactions with the recipient country governments. ${ }^{22}$

We expand upon the insights above by suggesting that the political agency of the targeted constituencies, themselves, can help explain subnational aid allocation. Rather than conceptualizing the "development dance" as a twopartner engagement, sub-national aid allocation is likely to depend on three-way dynamics between the donor, the recipient government, and the targeted constituencies whose interests may or may not be adequately represented in government. Indeed, subnational constituencies most in need are likely those that are also marginalized by their society and/or government. Thus, relying on constituent governments to advance the needs of these constituencies is a dicey proposition. Beyond this, there is likely to be heterogeneity even amongst the needy constituencies. In many countries, "the needy" will constitute numerous, diverse, groups and may, indeed, vie amongst themselves for resources. We propose that when these constituencies are sufficiently politically empowered, ${ }^{23}$ they may advance their own interests vis-à-vis an altruistic donor in two ways.

We first suggest that these constituencies can help their own cause by reducing the search costs of the donor. Similar to the "domestic expert" of Fang and Stone's formal treatment of 10 decision making, domestic constituencies may have private, or at least asymmetric, information about their own needs. ${ }^{24}$ Need-based metrics, such as income/wealth levels, health or education indicators, or equality measures may be difficult and expensive for donors to obtain, especially at a sufficiently localized, subnational, level that facilitates targeting community-based interventions. ${ }^{25}$ Empowered constituencies may have private information and will be strongly incentivized to present their "needs" case and this can reduce the costs for the donor in identifying whom to target. Beyond this, even when metrics are available, they may be crude and/or insufficient to determine true need, and empowered constituencies can provide donors with qualitative or narrative evidence of need.

This latter mechanism is closely linked to a second route of influence, empowered constituencies can serve as a gate keeper for donor access and input and output legitimacies. Altruistic donors are at pains to demonstrate to their

\footnotetext{
${ }^{21}$ Swedlund 2017a.

${ }^{22}$ Swedlund 2017a.

${ }^{23}$ For our purposes political empowerment may mean access to formal institutional structures such as key parliamentary or administrative roles but may also simply be constituencies that are wellorganized and empowered through non-governmental channels. We will elaborate on this in the empirical section below.

${ }^{24}$ Fang and Stone 2012.

${ }^{25}$ Galasso and Ravallion 2005; Bardhan and Mookherjee 2006.
} 
stakeholders that their efforts do indeed have a "pro-poor" focus. ${ }^{26}$ This can often come via endorsement of a needy constituency itself. ${ }^{27}$ Politically empowered, vocal and/or visible constituencies give donors both input and output legitimacy via facilitation of access to local engagement and support in the constituency, and recognition and confirmation of the effectiveness of the donor's efforts. Similarly, these groups can threaten ex post reputational costs if they are neglected in allocation by naming and shaming donors that have overlooked their needs. ${ }^{28}$

Key to the arguments above is the assumption of an altruistic donor actor. If a donor is unconcerned with addressing needy constituencies, in practice or even in perception, their allocation is unlikely to be swayed by the political empowerment of those constituencies. Sub-national allocation of egoistic donors is likely to follow their own interests if those interests have a geographic component, perhaps access to resources or to accompany a subnational geostrategic objective. ${ }^{29}$ Alternatively, egoistic donors without geographic preferences for aid allocation may simply leave it to recipient country governments to decide where to allocate aid. ${ }^{30}$ Our argument is that it is the combination and relative strength of these three influences - donor interests, recipient government political economy, and needy constituency empowerment - that can explain subnational aid allocation patterns. That said, when needy constituencies are unempowered, or donor's interests are purely egoistic, the dance reverts to two players.

\subsection{Subnational Allocation of World Bank Education Aid in India: Follow the Caste}

In order to evaluate our theoretical claims, we examine the case of World Bank education aid allocation in India. The donor, recipient and sectoral foci allow us to more precisely test the mechanisms we've outlined above. Focusing on the World Bank, as a multilateral donor actor, allows us to proceed with a

\footnotetext{
${ }^{26}$ Younas, 2008; Arbia and Carbonnier 2016.

${ }^{27}$ For example, in discussing a World Bank coffee project in Papua New Guinea, a local government official proclaimed, "We thank the World Bank ... for coming down to the village level to save our coffee gardens." Further information can be found at < http://www.looppng.com/content/villagers-praise-world-bank-and-partners-coffee-rehab-work> Accessed on 10 January 2018.

${ }^{28}$ As an example, a story of a local from the Tanzanian village of Mlanda who passes a barren pump on a $2 \mathrm{~km}$ walk to retrieve water, despite World Bank promises to improve the water supply. Further information can be found at <https://www.pri.org/stories/2014-11-24/world-banks-waterfailure-tanzania> Accessed on 11 October 2018.

${ }^{29}$ Lum, Fischer, Gomez-Granger and Leland 2009; Findley, Powell, Strandow and Tanner 2011; Zyck 2012; Bohnke and Zurcher 2013.

${ }^{30}$ Dreher, Langlotz and Marchesi 2017.
} 
reasonable assumption of donor altruism, from both a theoretical and empirical perspective. Multilateral aid allocation has been found to be explained by geographical distance, human development needs, favoritism, human rights conditions, recipient government quality, recipient governments' demand and core competency areas. ${ }^{31}$ Bilateral and multilateral donors have been differentiated based on the principal-agent considerations the latter. ${ }^{32}$ While strands of this literature focus on why bilateral donors might delegate foreign aid allocation to multilateral donors, ${ }^{33}$ other work more explicitly examines the "agency slack" that is opened to multilateral donors given the multiple and collective nature of their government principals. ${ }^{34}$ Indeed, recent work has found that World Bank projects are subject to informal influence through the project cycle. ${ }^{35}$ While some argue that multilateral donors are captured by their powerful principals, Copelovitch presents a theoretical argument and empirical evidence that multilateral donors both fall under the control of their powerful principals but also have areas of agency slack, depending on conditions. ${ }^{36}$ Despite these nuances, it is conventionally held that multilateral donors are more likely to be altruistic in their decision making. ${ }^{37}$

From a recipient standpoint, focusing on India allows us to utilize the unique and persistent social structures of that country in determining and differentiating needy constituencies. The prevailing cause of social inequality in Indian society is caste identity. The caste system entails a division of labor, wherein Brahmin is the priestly class, Kshatriya is the military class, Vaishya is the merchant class and Shudra comprises artisans and menial workers. Outside this system falls "Dalits" and indigenous inhabitants. ${ }^{38}$ The caste system is a selfenclosed unit which assigns people in society by virtue of birth rather than training and occupation. ${ }^{39}$ As a product of the historical encounter between Indian and colonial rule, this system not only lowers market efficiency and individual mobility, but also solidifies conditions of inequality in many aspects. Indeed, $45.9 \%$ of scheduled tribes and $26.6 \%$ of scheduled castes are in the lowest wealth bracket. ${ }^{40}$ Yet SC/ST is not directly synonymous with wealth, and

\footnotetext{
${ }^{31}$ Alesina and Dollar 2000; Eric 2003; Neumayer 2003; Zhang 2004; Winters 2010; Humphrey and Michaelowa 2013; Öhler and Nunnenkamp 2014; Stubbs, Kentikelenis and King 2015.

32 Martens 2000; Milner 2006; Winters 2010; Eichenauer and Hug 2018.

33 Schneider and Tobin 2013; Milner and Tingley 2013; Eichenauer and Reinsberg 2017.

${ }^{34}$ Martens 2005; Eichenauer and Hug 2018.

${ }^{35}$ Malik and Stone 2015.

${ }^{36}$ Fleck and Kilby 2006; Dreher and Jensen 2007; Dreher, Sturm and Vreeland 2009; Copelovitch 2006.

${ }^{37}$ Thiele, Nunnenkamp and Dreher 2007; Clist, Isopi and Morrisey 2012.

${ }^{38}$ Pellissery, Pampackal and Bopaiah 2015.

${ }^{39}$ Ambedkar 2014, 30.

${ }^{40}$ Government of India 2018.
} 
as such the classifications allows us to identify and compare empowered and non-empowered needy constituencies within the more general "poor".

Finally, examining education aid enables us to focus on a distinctly "propoor" sector. ${ }^{41}$ Unlike other development sectors, there is a decent consensus that education aid "works" at least when considering quantity metrics like enrollment or repetition rates. ${ }^{42}$ While there is some evidence that in recent years education aid has become more entwined donor geo-strategic interests, ${ }^{43}$ it remains a sector that is least likely to be driven by donors' egoistic interests, especially given that payoffs from investment in education take years if not decades to materialize. Accordingly, focusing on World Bank education aid in India gives us a most likely case for observing the impact of empowered needy constituencies on patterns of aid allocation.

\subsection{Caste, Education and the World Bank in India}

Substantial work has examined the impact of the caste system on access to education and education development. ${ }^{44}$ This scholarship indicates that the caste system causes durable inequality in education and different levels of educational achievement, employment outcomes and access to economic resources. ${ }^{45}$ These results are often amplified by gender as women in lower castes have even more limited access to education and employment. ${ }^{46}$ Exclusion in education is also closely associated with broader social exclusion. ${ }^{47}$ These inequalities persist despite provisions in the Indian Constitution to explicitly deal with this discrimination. Articles 16 and 17 of the Constitution of India guarantee equality of opportunity and abolish the practice of untouchability by emphasizing that:

No citizens shall, on grounds only of religion, race, caste, sex, descent, place of birth, residence or any of them, be ineligible for, or discriminated against in respect of, any employment or office under the State. ${ }^{48}$

\footnotetext{
${ }^{41}$ Thiele, Nunnenkamp and Dreher 2007.

${ }^{42}$ D'Aiglepierre and Wagner 2013.

${ }^{43}$ Novelli 2010.

44 Tilak 1979; Dunn 1993; Borooah and Iyer 2005; Scaria 2014; Halim, Yount and Cunningham 2016.

45 Filmer and Pritchett 2001; Deshpande and Newman 2007; Borooah 2012; Scaria 2014; Pellissery, Pampackal and Bopaiah 2015.

${ }^{46}$ Dunn 1993; Halim, Kathryn and Solveig 2016.

${ }^{47}$ Hann 1999.

48 The Government of India 1950.
} 
"Untouchability" is abolished and its practice in any form is forbidden. The enforcement of any disability arising out of "Untouchability" shall be an offence punishable in accordance with law. ${ }^{49}$

Despite these provisions, exclusion in education is still a main ritual marker of lower caste status. ${ }^{50} \mathrm{~A}$ report from the Social and Rural Research Institute indicated that, as of $2014,3.24 \%$ of SC children and $4.20 \%$ of ST children are still not enrolled in school. ${ }^{51}$ Alienation, social exclusion and physical abuse occur from primary education to university and are likely to contribute to low enrollment and high drop-out rates among Dalit children. ${ }^{52}$

The World Bank has a long history of education programs in India, but the subnational allocation of this aid has not been directly studied. ${ }^{53}$ Before the 1990s, the school system in India was mainly domestically financed. However, in the early 1990s, a widening gap between public expenditure and revenues required the Government of India to reduce expenditure on education. ${ }^{54}$ Following the aid commitments from the World Conference on Education for All in 1990, international donors like the World Bank and IMF increased their attention on basic education. Meanwhile, as a result of constitutional reform, school management responsibilities were gradually transferred to local bodies at district, village and block. ${ }^{55}$ Guided by the Eighth Plan Document (1992-1997), the development of education became more targeted by a shift in focus from educationally backward states to educationally backward districts. ${ }^{56}$ Ensuring "the right to education" has long been a World Bank goal. ${ }^{57}$ To protect "the right to education", the World Bank has emphasized the rights to education in vulnerable groups in society, which includes women, refugees, those subject to involuntary resettlement, as well as indigenous people. Protection of these groups have been built into projects with policy prescriptions. ${ }^{58}$ Accordingly, the World Bank has paid strong rhetorical homage to the education rights of minorities when initiating and implementing education projects. In a report titled Learning to Be published in 1972 the World Bank argued:

\footnotetext{
49 The Government of India 1950.

50 The World Bank 2011.

${ }^{51}$ Social and Rural Research Institute 2014.

${ }^{52}$ Borooah and Iyer 2005.

${ }^{53}$ While Nunnenkamp et al. found that the World Bank prefers districts where foreign direct investors may benefit from projects related to infrastructure, they did not explicitly examine the allocation of education aid.

${ }^{54}$ Tilak 2008.

${ }^{55}$ Colclough and De 2010.

${ }^{56}$ Relevant documents about The National Plans from the Government of India can be accessed at $<$ http://planningcommission.nic.in/plans/planrel/index.php?state=planbody.htm>.

${ }^{57}$ Oestreich 2004.

${ }^{58}$ Omprasad 2016.
} 
The universal right to education-in which contemporary civilization takes such premature pride-is often refused, by a complete reversal of justice, to the most underprivileged. They are the first to be denied their right in poor societies, the only once deprived in the rich (Faure et al. 1972). ${ }^{59}$

In the context of India, World Bank documents commonly mention the caste system in arguing that social constructions that are shared with a culture shape how people perceive and understand the world and themselves. The caste system is regarded as a source of concepts, shared community, narratives and worldviews that can give higher-caste individuals access to social insurance, jobs, and dominance over individuals in lower-ranked castes. ${ }^{60}$ The World Bank further acknowledges that the caste structure produces significant gaps in performance, with the high castes learning more and working more productively than the low castes. ${ }^{61}$ World Bank president Jim Yong Kim noted in addressing the Vibrant Gujarat Summit that caste bias is always a concern of the World Bank and allocation of funds for entrepreneurs from among the scheduled castes should be ethically just and economically sound. ${ }^{62}$ Similarly, expanded human development lending in the World Bank's 2004 Country Strategy for India was predicated on the continuing substantial disparity of opportunity, particularly in the education, health and economic prospects of women and other vulnerable groups like SC and ST populations. Likewise, the Scheduled Caste and Scheduled Tribe Development Plan outlines mitigating measures to solve problems of exclusion in education, including developing soft skill and entrepreneurial modules, managing a data bank on students, promoting outreaching activities for community awareness, training on social inclusion and gender sensitization. Thus, the official rhetoric surrounding the allocation of World Bank education aid in India contains an explicit and continued pro-poor focus, particularly for SC/STs.

However, paying homage to SC/STs in official documents may simply be "cheap talk" that does not necessarily translate in observed patterns of aid allocation. ${ }^{63}$ In order to understand if the World Bank's apparent altruism translated to increased SC/ST allocation targeting, we need to understand the interplay between the Bank, the Indian government authorities, and the SC/ST

\footnotetext{
${ }^{59}$ Faure, Herrera, Kaddoura, Lopes, Petrovsky, Rahnema and Ward 1972.

${ }^{60}$ The World Bank Policy Research Working Paper Caste System drafted by Karla Hoff explained this issue. Hoff 2016.

${ }^{61}$ The World Bank Policy Research Working Paper Making Up People- The Behavioural Effects of Caste illustrated this topic. Hoff, Pandey 2011.

${ }^{62}$ The Times of India 2015.

${ }^{63}$ Dreher, Langlotz and Marchesi 2017.
} 
groups themselves. The World Bank's elementary education aid in India is delivered through projects. After investigating relevant documents of the World Bank's elementary projects in India, it is evident that the World Bank signed project agreements with Government of India to propose policy implementation in specific districts. ${ }^{64}$ For instance, in the District Primary Education Project II, the International Development Association (IDA) directly negotiated with twelve Indian states to identify a list of districts the World Bank planned to fund. ${ }^{65}$ In contrast, in the Uttar Pradesh Third District Primary Education Project, it was the Government of India who worked with the IDA to clarify rights and responsibilities.

At the level of implementation, the relationship between the World Bank and Central Government of India is fixed by project agreements, which guarantees information flow and makes monitoring and accountability easier. ${ }^{66}$ The implementation agency of the Bank's education projects in India are mainly local governments. ${ }^{67}$ Non-governmental actors also sought to influence the nature and implementation of these projects. The International Dalit Solidarity Network (IDSN) recommended governments to take appropriate measures to ensure Dalits' right to equal participation and non-discrimination in education, reporting that belonging to a scheduled cates or tribe lowers prospects of school attendance. $^{68}$

Given the discussion above, we develop two expectations about pattern of World Bank education aid allocation in India. First, given the explicit focus of both the World Bank and the Indian government on SC/STs we expect increased allocation to those areas with high proportions of these marginalized poor above and beyond targeting toward the general "poor". Second, given the mechanism of reducing search costs and increasing input and output legitimacy, we expect this effect to be amplified in locations where the SC/ST is politically empowered.

\footnotetext{
${ }^{64}$ There were 15 elementary education projects in India from the World Bank from 1991 to 2011. And each project offered series of documents including Memorandum \& Recommendation of the President, project agreements, credit agreements, implementation completion and results reports and implementation report reviews. The authors reviewed these documents and found that project agreements are normally singed between International Development Association and Indian States to be allocated, or between International Development Association and Government of India.

${ }^{65}$ These states include Assam, Gujarat, Haryana, Himachal Pradesh, Karnataka, Kerala, Madhya Pradesh, Maharashtra, Orissa, Tamil Nadu, Uttar Pradesh and Chhattisgarh. Relevant information can be found at http://documents.worldbank.org/curated/en/165161468034514343/pdf/PA0Amendment0Jan02110 20031cc1.pdf

${ }^{66}$ Radelet 2006.

${ }^{67}$ We explored the World Bank education projects documents in India from 1992 through 2014 to find that implementation agencies in these projects were all state governments of India.

${ }^{68}$ IDSN 2010.
} 


\section{Data and Methods}

To examine our marginalized poor and political empowerment hypotheses, we apply cross-sectional data covering 593 districts from 29 states and seven Union Territories in India (Appendix 1) for the 2001 period. We use the World Bank Geocoded Aid Data v1.4.2 from AidData and Census of India 2001 handbook sourced from the Ministry of Home Affairs, Government of India, that provide data on social and economic indicators at the district level. We formulate crosssectional data by matching these two datasets and then add additional control variables sourced from the Reserve Bank of India. Since some of the data are not available for all districts and for all years, our dataset is unbalanced. We thus estimate:

$$
\begin{aligned}
& \ln (W B)_{d i t}=\beta_{1} S C M P_{d i t}+\beta_{2} S C_{d i t}+\beta_{3} S C \text { census }_{d i t}+\beta_{4} \phi_{d i t}+\varepsilon_{d i t} \\
& \ln (W B)_{d i t}=\beta_{1} S T M P_{d i t}+\beta_{2} S T_{d i t}+\beta_{3} S T \text { census }_{d i t}+\beta_{4} \phi_{d i t}+\varepsilon_{d i t}
\end{aligned}
$$

where in equation (1) and (2), $\ln (W B)_{d i t}$ is the outcome variable of interest, $\phi_{i t}$ are the control variables (discussed below) and $\varepsilon_{d i t}$ is error term. The term $\ln (W B)_{\text {dit }}$ measures the World Bank elementary education aid in district $\boldsymbol{d}$, state $\boldsymbol{i}$ at year $\boldsymbol{t}$ (2001). To control for skewness, we log the World Bank education aid variable. The base data is sourced from the World Bank Geocoded Aid Data v1.4.2 available with the AidData. ${ }^{69}$ We focus on one broad education initiative from the World Bank, the District Primary Education Project (DPEP) which was disbursed in seven different project waves from 1994 to 2001. Note that DPEP data is available at the project-level and doesn't vary by year and hence our data is cross-sectional. While the AidData database has information on these waves, the geographic precision for many of these projects is only at the state level. However, Azam and Saing identify which districts within states have received DPEP and we combine that with the AidData project records to create a measure of district-level aid. ${ }^{70}$ In total, 268 districts received at least one wave of DPEP financing in amounts ranging from roughly US\$3 million to US\$10 million. We estimate OLS estimation specification which include Huber-White corrected robust standard errors, a method which is robust to heteroskedasticity and serial correlation. ${ }^{71}$

There are three key variables in equation (1) and (2) which merit discussion. First is the SC and the ST population shares in district $\boldsymbol{d}$, state $\boldsymbol{i}$ at year $\boldsymbol{t}$ respectively. The data for both SC and ST population and total population for

\footnotetext{
${ }^{69}$ AidData 2017.

${ }^{70}$ Azam and Saing 2016.

${ }^{71}$ Wiggins 1999.
} 
each district is sourced from the government of India census handbooks. Second, is the SC and ST MPs which is a count of number of elected MPs from SC and ST reserved constituencies and 0 for non-reserved constituencies. The challenge we encounter in compiling this data is that the electoral constituencies in India do not overlap with administrative districts' boundaries in the states, a problem also faced by other studies in the literature. ${ }^{72}$ We make use of the documents available at the Election Commission of India that provide information about the boundaries of administrative districts and electoral constituencies in each state which was in turn used to match the individual constituencies reserved for SCS and STs to the administrative districts. The geographic distribution of World Bank educational aid and SC/ST MPs are shown in Map 1 below.

Map 1: World Bank Educational Aid and SC/ST MPs

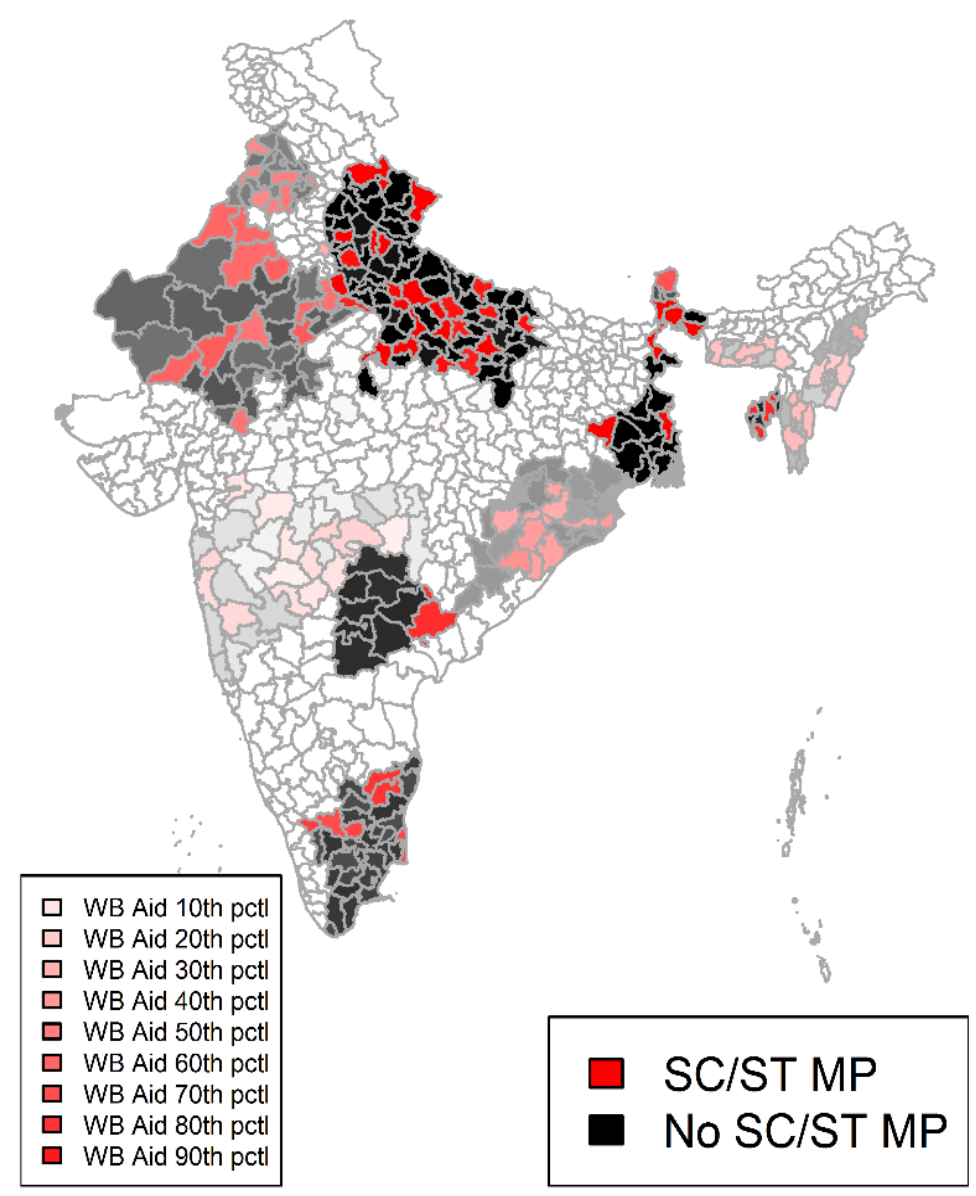

Third, as seen in equation (1) and (2) we also include SC and ST population share from past census (of 1971) for district $\boldsymbol{d}$, state $\boldsymbol{i}$ at year $\boldsymbol{t}$ (2001).

\footnotetext{
72 Aidt and Franck 2015; Vadlamannati 2011; Vadlamannati 2016; Gehring, Kauffeldt and Vadlamannati 2018
} 
The main reason for including SC and ST population shares from 1971 is that without them estimating equations (1) and (2) could have an endogeneity problem. It is quite unlikely that our key explanatory variables - SC and ST population shares - are endogenous to World bank aid allocation. In other words, SC and ST population shares are unlikely to be a result of aid allocation decisions of the Bank. An

important concern, though, remains. If the World Bank aid allocation in Indian districts is a function of SC and ST population then it is also correlated with Parliamentary seats reserved for SC and ST candidates.

This correlation is due to the fact that a 'policy rule' reserves parliamentary seats for SC and ST candidates on the basis of population share. ${ }^{73}$ This rule is one of several affirmative action policies enshrined in the Indian Constitution to improve the wellbeing of the SC and ST populations. Once reserved, only members from SC and ST communities, irrespective of political parties, should contest elections from those reserved seats. ${ }^{74}$ Voters from all other castes (social/ethnic groups) get to vote in those reserved constituencies. To get around this endogeneity we take advantage of the fact that there is often a substantial time lag in implementation of this 'policy rule'. ${ }^{75}$ This is due to the multiple institutional steps involved in the rule. First, there is a passage of time between the release of new census data and the establishment of the Delimitation Commission which apportions seats. Second the Delimitation Commission then takes several years to arrive at new reservation quotas for SCS and STs in each state based on the new census numbers. Finally, the state itself could take several more years (after deliberations and consultations in the Parliament and respective state legislative assemblies) to implement the new revised constituencies.

Beyond this general institutional lag, a constitutional amendment in 1976 suspended the Delimitation Commission until the year $2000 .^{76}$ This effectively

\footnotetext{
${ }^{73}$ The Registrar of India conducts a census in each state to count the population numbers. The census exercise is undertaken once in every 10 years. These census numbers are then submitted to the central government which then appoints a "Delimitation Commission", which is a national committee comprising of chief national election commissioner, judges from state High court and Supreme court. The Delimitation Commission is appointed after the arrival of new census which will then determine how many Parliamentary seats are to be reserved for SC and ST candidates based on new census numbers. Depending upon changes in SC and ST population numbers in each state the specific constituencies reserved for SCs and STs are revised. Notice that though districtlevel SC and ST population shares are used by the government to reserve constituencies for SCs and STs but geographic districts and electoral constituencies in India do not overlap.

${ }^{74}$ There is very little evidence to suggest that SC and ST candidates contest non-SC and ST electoral constituencies, i.e., those seats which are not reserved for SCs and STs.

${ }^{75}$ Chinn and Prakash 2011.

${ }^{76}$ An important aspect of this suspension was that the number of Parliamentary constituencies and seats in the state legislative assemblies were frozen until the year 2000.
} 
means that the SC and ST Parliamentary seats for the elections from 1978 to $2008^{77}$ were reserved based on the SC and ST population census numbers of 1971. In 2002, the government of India, through the Delimitation Commission Act of 2002, set up a new commission to adjust the territorial boundaries of the electoral constituencies and the reservations of SC and ST seats on the basis of 2001 census numbers. ${ }^{78}$ As a result, the number of seats reserved for SCs in lower house of the Parliament jumped from 78 to 84 and for STs the reserved seats increased from 41 to 47.

Exhibit 1 displays how the 'policy rule' works. As seen, the SC and ST seat shares in each state for 1968, 1972 and 1976 elections were based on 1961 census numbers, while the seats for the same in 1980 to 2004 elections were reserved based on 1971 census numbers. Because of this time lag, we need to control for SC and ST population shares in each district from the 1971 census for period 2001 based on which the changes to the reserved seats was determined by the Commission. ${ }^{79}$ As population changes every year, we expect that the current SC and ST population share, which is our main variable of interest, will be different from both the SC and ST population share measured in the past census (of 1971) and the districts which are reserved seats for SC and ST candidates. This strategy allows us to identify the causal effects coming from elected SC and ST MPs and not merely from the current SC and ST population share and still control for the past census numbers.

\footnotetext{
${ }^{77}$ The Delimitation Commission of 1971 submitted its report which was implemented from 1978 onwards. Therefore, the reserved SC and ST seats for all the national and state elections from 1978 onwards were based on the 1971 census numbers.

${ }^{78}$ It is noteworthy that the new Delimitation Act of 2002 extended the freeze of number of Parliamentary constituencies and seats in the state legislative assemblies until the year 2026 but allowed for adjustment of SC and ST constituencies in line with the changes in their respective population numbers in districts on the basis of 2001 census.

${ }^{79}$ This is similar to the strategy adopted by Pande (2003), Chinn and Prakash (2011) and Howard and Prakash (2012).
} 
Exhibit 1: 'Policy Rule' of reservations of SC and ST Parliamentary seats in India

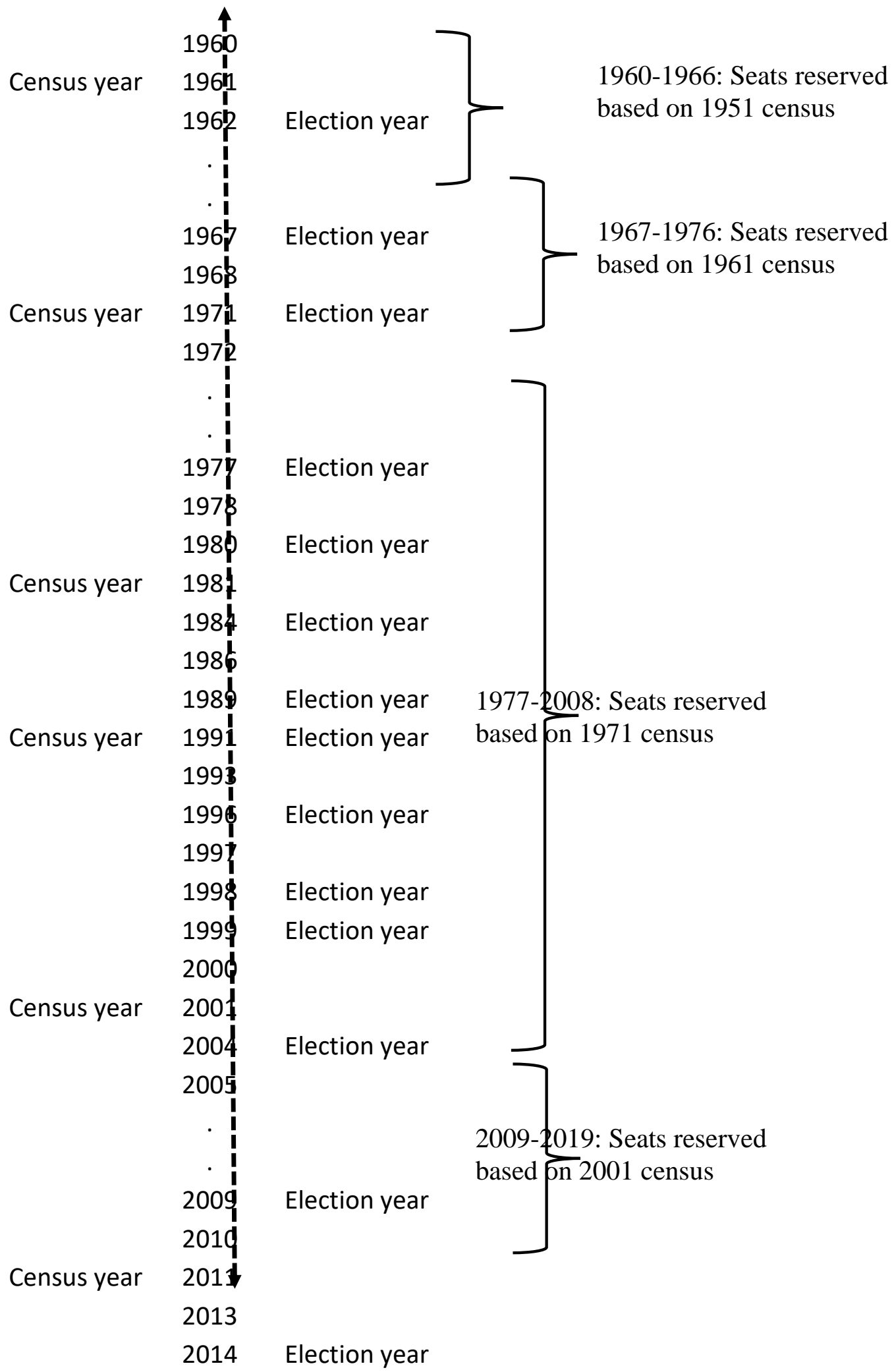


Next, we further operationalize our political empowerment hypothesis by considering the differential effect of SC and ST MPs when they are in government. In order to do this, we estimate a model in line with Khemani. ${ }^{80}$

$$
\begin{aligned}
\ln (W B)_{d i t}= & \beta_{1}(S C M P S \times \text { Affiliation })_{\text {dit }} \\
& +\beta_{2}(\text { SCMPs } \times[1-\text { Affiliation }])_{\text {dit }} \\
& +\beta_{3} \text { Affiliation } \text { dit }+\beta_{4} \phi_{\text {dit }}+\varepsilon_{\text {dit }} \text { (3) } \\
& \ln (\text { WB })_{\text {dit }}=\beta_{1}(\text { ST MPs } \times \text { Affiliation })_{\text {dit }} \\
+ & \beta_{2}(\text { ST MPs } \times[1-\text { Affiliation }])_{\text {dit }} \\
+ & \beta_{3} \text { Affiliation } \text { dit }_{\text {dit }}+\beta_{4} \phi_{\text {dit }}+\varepsilon_{\text {dit }} \text { (4) }
\end{aligned}
$$

wherein, Affiliation $_{\text {dit }}$ is an indicator of political affiliation that equals 1 when the political affiliation of SC and ST MPs from district $\boldsymbol{d}$ at time $\boldsymbol{t}$ belongs to the same party as that governing at the center at time $t$, and 0 otherwise. Note that we control for current (2001) and past (based on 1971 census) population share of SCs and STs in equation (3) and (4) respectively. If political empowerment stems from SC and ST MPs being politically aligned with the central government, we could have $\boldsymbol{\beta}_{1}>\mathbf{0}$ and $\boldsymbol{\beta}_{\mathbf{2}}<\mathbf{0}$ from both equation (3) and (4). Conversely, if partisan identity of the SC and ST MPs does not matter for the ruling party in center, then $\beta_{1}$ would be indistinguishable from 0 . Once again, we employ OLS estimator controlling for Huber-White corrected robust standard errors.

Finally, the vector $\phi_{i t}$ includes control variables at the Indian districtlevel which are gleaned from the existing literature on aid allocation at Subnational level. ${ }^{81}$ In selecting the controls, we try to avoid the "garbage can" approach and limit our control variables. ${ }^{82}$ We follow the conservative strategy of accounting only for known factors that may confound the effect of SC and ST population share, such as level of income, spending on education and the current level of literacy. We include district-wise total population (log) as larger districts might need more resources to obtain visible effects of aid provision. ${ }^{83}$ We also control for state capacity by including two measures. First, in the absence of data on government spending on education at district level, we include each state government's total expenditure $(\log )$ at the state-level which varies by year in a

\footnotetext{
${ }^{80}$ Khemani 2007.

${ }^{81}$ Dreher, Nunnenkamp and Thiele 2008; Nunnenkamp, Öhler and Andrés 2016; Briggs 2017.

${ }^{82}$ Achen 2005.

${ }^{83}$ Roberts 2003; Nunnenkamp, Öhler and Andrés 2016.
} 
state but not by district within each state. Second, following Gupta et al., ${ }^{84}$ we include state government's expenditure on primary education $(\log )$ at the statelevel which again varies by year in a state but not by district within each state. Likewise, to measure the remoteness of each district vis-a'-vis the district headquarters (i.e., capital of the state), we compute the distance from each district in a state to the capital of that particular state measured in kilometres (log). 85

In considering general district-level need, we consider three proxies. First, we expect the World Bank to provide more education aid to districts with a larger rural population share where poverty is high and educational infrastructure is limited. This variable serves as one of our proxies for general recipient need. ${ }^{86}$ Next, we expect districts with lower levels of literacy to attract more educational aid from the World Bank, serving as a measure of educational need. Following others, ${ }^{87}$ we include male and female literacy rate drawn from the Government of India's Census handbooks. Finally, we use night-time lights as a proxy for the economic development of the districts. Unfortunately, there are no official GDP or per capita GDP estimates available at the district level in India, so we rely on night light satellite images. Henderson et al. show how to calculate night-time lights data and show that it is correlated with official GDP growth data. ${ }^{88}$ Likewise, both Chaturvedi and Gehring et al. have used night-time lights data as a proxy for economic development in electoral constituencies in India. ${ }^{89}$ These studies emphasize that night light data is the best available objective measure of economic development in countries where official data on GDP is not always available. We use average visible, stable light on cloud free nights, collected by the F16 satellite for the years 1992, and 2001. We then compute the log sum of lights using zonal statistics within each district to proxy for economic development. The descriptive statistics are provided in Appendix 2 and details on data definitions and sources in Appendix 3.

\footnotetext{
${ }^{84}$ Gupta, Verhoeven and Tiongson 1999.

${ }^{85}$ Nunnenkamp, Öhler and Andrés 2016; Vadlamannati 2011.

${ }^{86}$ Dollar and Levine 2006.

${ }^{87}$ Baldacci, Clements, Gupta and Cui 2004 ; Michaelowa and Weber 2006; Dreher, Nunnenkamp and Thiele 2008.

${ }^{88}$ Henderson, Storeygard and Weil 2012.

${ }^{89}$ Chaturvedi 2011; Gehring, Kauffeldt and Valamannati 2018.
} 


\section{Empirical Results}

Table 1 reports the impact of SC and ST population shares on World Bank educational aid allocation. While columns 1-2 present the results from a parsimonious model, columns 3-4 present the results of SC and ST population share on World Bank aid allocation controlling for past population shares.

Table 1: World Bank education aid allocation and SC, ST population share

\begin{tabular}{|c|c|c|c|c|}
\hline & (1) & (2) & (3) & $(4)$ \\
\hline & WB Aid (ln) & WB Aid (ln) & WB Aid (ln) & WB Aid (ln) \\
\hline \multirow[t]{2}{*}{ SC Population share (Current) } & $0.206^{* * *}$ & & $0.159^{*}$ & \\
\hline & $(0.0467)$ & & $(0.0940)$ & \\
\hline \multirow[t]{2}{*}{ ST Population share (Current) } & & -0.0199 & & -0.0348 \\
\hline & & $(0.0197)$ & & $(0.0433)$ \\
\hline \multirow[t]{2}{*}{ SC Population share (Past) } & & & 0.0573 & \\
\hline & & & $(0.0922)$ & \\
\hline \multirow[t]{2}{*}{ ST Population share (Past) } & & & & 0.0150 \\
\hline & & & & $(0.0406)$ \\
\hline \multirow[t]{2}{*}{ Population (log) } & 0.200 & 0.348 & 0.159 & 0.315 \\
\hline & $(0.568)$ & $(0.596)$ & $(0.570)$ & $(0.599)$ \\
\hline \multirow[t]{2}{*}{ Rural Population share } & 3.067 & 5.272 & 3.418 & 5.232 \\
\hline & $(3.466)$ & $(3.404)$ & $(3.466)$ & $(3.420)$ \\
\hline \multirow[t]{2}{*}{ Literacy Rate } & $-0.171^{* * *}$ & $-0.170^{* * *}$ & $-0.167^{* * *}$ & $-0.171^{* * *}$ \\
\hline & $(0.0340)$ & $(0.0351)$ & $(0.0343)$ & $(0.0352)$ \\
\hline \multirow[t]{2}{*}{ Elementary Education Expenditure (log) } & $3.646^{* * *}$ & $3.526^{* * *}$ & $3.692^{* * *}$ & $3.553^{* * *}$ \\
\hline & $(1.007)$ & $(0.960)$ & $(1.004)$ & $(0.962)$ \\
\hline \multirow[t]{2}{*}{ Government Expenditure (log) } & -1.064 & -0.578 & -1.158 & -0.600 \\
\hline & $(1.165)$ & $(1.168)$ & $(1.157)$ & $(1.172)$ \\
\hline \multirow[t]{2}{*}{ Night Light (log) } & $-0.194^{*}$ & -0.152 & $-0.197^{*}$ & -0.154 \\
\hline & $(0.108)$ & $(0.104)$ & $(0.109)$ & $(0.104)$ \\
\hline \multirow[t]{2}{*}{ Distance to State Capital (log) } & -0.209 & -0.216 & -0.221 & -0.232 \\
\hline & $(0.444)$ & $(0.461)$ & $(0.443)$ & $(0.462)$ \\
\hline \multirow[t]{2}{*}{ Constant } & $-15.92^{* *}$ & $-19.51^{* *}$ & $-15.55^{\star *}$ & $-18.93^{* *}$ \\
\hline & $(6.882)$ & $(8.763)$ & $(6.894)$ & $(8.803)$ \\
\hline Total Observations & 545 & 545 & 544 & 544 \\
\hline Estimator & OLS & OLS & OLS & OLS \\
\hline Number of States & 29 & 29 & 29 & 29 \\
\hline Number of Districts & 545 & 545 & 544 & 544 \\
\hline R-squared & 0.271 & 0.248 & 0.273 & 0.249 \\
\hline
\end{tabular}

Notes: Robust standard errors in parenthesis; Statistical significance: ${ }^{* * *} p<0.01$, ${ }^{* *} p<0.05, * p<0.1$ 
As seen from columns 1-2, the SC population share is positive and significantly different from zero at the $1 \%$ level. We find no significant effect of ST population share on World Bank aid allocation. But as discussed in previous section, estimates from columns 1-2 may be biased due to an omitted variable bias problem. We therefore control for the past values of SC and ST population shares. In columns 3-4, the effects of SC and ST populations are similar to columns 1-2 after controlling for past census population shares of SCs and STs in the districts. As seen in column 3 , the substantive effects suggest that a standard deviation increase in SC population share (8.72) is associated with an increase in World Bank aid allocation by $150 \%$, which is significantly different from zero at the $10 \%$ level.

ST population share, as shown in column 4, has no significant effect in allocation of World Bank aid in Indian districts. There could be multiple reasons for this finding. One plausible explanation could be that, compared to SC population, majority of the ST population resides in rural, and sometimes remote, areas in Indian districts. Chinn and Prakash show that about 90\% of the ST population resides in rural areas while only $2.4 \%$ of the ST population live in urban areas. ${ }^{90}$ The poverty rate of this community is twice that of SC population which inhabit in urban areas. As such, we might expect that World Bank exerts efforts to reach out to these communities by focusing on rural areas to improve ST well-being. However, the reach of the Indian government machinery to some of these rural areas is limited. In a UN survey report, Sujatha points out the difficulties faced by the government administrative apparatus to take some of the government educational schemes to the ST districts which are in remote parts of the country. ${ }^{91}$ Similar such findings are echoed in the work by Nair. ${ }^{92}$

\subsection{Political empowerment effects}

Next, we examine whether the World Bank aid allocation in Indian districts is conditional on the presence of SC and ST MPs, controlling for their population shares. In Table 2, we introduce new variables into our baseline models, i.e., if a district is represented by a SC or ST MP. As seen in columns 1-3, we find positive effects, but these are only statistically significant at the $10 \%$ level for ST MPs (columns 2-3), although the substantive effect is large: a district represented by SC MPs is associated with roughly $175 \%$ increase in World Bank aid allocation. ${ }^{93}$ These findings are in line with Chinn and Prakash, and Pande, who find that at

\footnotetext{
${ }^{90}$ Chin and Prakash 2011.

${ }^{91}$ Sujatha 2000.

${ }^{92}$ Nair 2007.

${ }^{93}$ Note that our results remain robust even after sequentially expanding the main explanatory variables i.e., the SC and ST population shares from 1971, followed by the current SC/ST population shares.
} 
the state-level, political reservations for minority groups, especially STs in India, does have some positive impact in reduction in overall poverty. ${ }^{94}$

Table 2: World Bank education aid allocation and SC, ST MPs

\begin{tabular}{|c|c|c|c|}
\hline & (1) & (2) & (3) \\
\hline & WB Aid (ln) & WB Aid (ln) & WB Aid (ln) \\
\hline \multirow[t]{2}{*}{ SC MPs } & 1.096 & & 1.157 \\
\hline & $(0.800)$ & & $(0.809)$ \\
\hline \multirow[t]{2}{*}{ SC Population share (Current) } & 0.139 & & 0.161 \\
\hline & $(0.0946)$ & & $(0.0997)$ \\
\hline \multirow[t]{2}{*}{ SC Population share (Past) } & 0.0536 & & 0.0560 \\
\hline & $(0.0914)$ & & $(0.0929)$ \\
\hline \multirow[t]{2}{*}{ ST MPs } & & $1.751^{*}$ & $1.861^{*}$ \\
\hline & & $(0.971)$ & $(0.947)$ \\
\hline \multirow[t]{2}{*}{ ST Population share (Current) } & & -0.0460 & -0.0179 \\
\hline & & $(0.0421)$ & $(0.0418)$ \\
\hline \multirow[t]{2}{*}{ ST Population share (Past) } & & 0.00826 & 0.0213 \\
\hline & & $(0.0398)$ & $(0.0388)$ \\
\hline \multirow[t]{2}{*}{ Population (log) } & 0.144 & 0.124 & 0.0813 \\
\hline & $(0.571)$ & $(0.613)$ & $(0.620)$ \\
\hline \multirow[t]{2}{*}{ Rural Population share } & 3.536 & 5.017 & 3.405 \\
\hline & $(3.463)$ & $(3.410)$ & $(3.474)$ \\
\hline \multirow[t]{2}{*}{ Literacy Rate } & $-0.169^{* * *}$ & $-0.171^{* * *}$ & $-0.164^{* * *}$ \\
\hline & $(0.0345)$ & $(0.0351)$ & $(0.0346)$ \\
\hline \multirow[t]{2}{*}{ Elementary Education Expenditure (log) } & $3.652^{* * *}$ & $3.522 * * *$ & $3.614^{* * *}$ \\
\hline & $(0.995)$ & $(0.958)$ & $(0.992)$ \\
\hline \multirow[t]{2}{*}{ Government Expenditure (log) } & -1.132 & -0.574 & -0.944 \\
\hline & $(1.152)$ & $(1.163)$ & $(1.173)$ \\
\hline \multirow[t]{2}{*}{ Night Light (log) } & $-0.199 *$ & -0.159 & $-0.197^{*}$ \\
\hline & $(0.109)$ & $(0.104)$ & $(0.109)$ \\
\hline \multirow[t]{2}{*}{ Distance to State Capital (log) } & -0.192 & -0.311 & -0.313 \\
\hline & $(0.441)$ & $(0.464)$ & $(0.446)$ \\
\hline \multirow[t]{2}{*}{ Constant } & $-15.19^{* *}$ & $-15.47^{*}$ & $-15.80^{*}$ \\
\hline & $(6.911)$ & $(9.052)$ & $(8.934)$ \\
\hline Total Observations & 544 & 544 & 544 \\
\hline Estimator & OLS & OLS & OLS \\
\hline Number of States & 29 & 29 & 29 \\
\hline Number of Districts & 544 & 544 & 544 \\
\hline R-squared & 0.275 & 0.252 & 0.281 \\
\hline
\end{tabular}

Notes: Robust standard errors in parenthesis; Statistical significance: ${ }^{* * *} p<0.01$, $* * p<0.05, * p<0.1$

To further test the political agency hypothesis, we present the results on political affiliation of SC and ST MPs in Table 3. In column 1 and 3 we present the results from parsimonious models of SC and ST MPs political affiliations, respectively, while including control variables in column 2 and 4 . In all models in Table 3, SC and ST MP political affiliation with the same political party as the central

${ }^{94}$ Pande 2003; Chinn and Prakash 2011. 
government leads to significantly higher World Bank aid allocations. For instance, districts represented by SC MPs see an increase in World Bank aid allocation by $814 \%$ if they are affiliated to the ruling party in the central government. The effects of affiliated ST MPs are also large, with those districts seeing an increase in World Bank aid allocation of 508\%. Interestingly, those SC and ST MPs who are not affiliated to the ruling party in the center have no effect on World Bank aid allocation. It is noteworthy that these effects are substantially larger than that of the control variables in the model. This suggests that it is the SC and ST MPS political relationship with the center that accounts for significant variation in aid allocation of World Bank. Our results give further credence to our political empowerment hypothesis.

With respect to control variables, we do not find population and rural population share to be significant determinants of development aid projects in education sector from the World Bank. However, we do find that night-time light variable, our proxy for economic development in districts, remains negative and is often statistically significant at the $10 \%$ level in models shown in Table 1-3. These findings are in line with the findings of Dreher et al. ${ }^{95}$ For instance, a standard deviation increase in night-time lights is associated with roughly $126 \%$ decrease in World Bank aid allocation. These findings provide some support for the general need-based criteria of the Bank in determining aid allocation in Indian districts. Likewise, we also find that literacy rate in districts is a strong determinant of World Bank aid allocation. These findings are in line with that of Nunnenkamp et al. who find some evidence of needs-based allocation of aid from the Bank in India. ${ }^{96}$ These results suggest that allocation based on being politically empowered marginalized constituencies is above and beyond targeting that also incorporates both educational need and a measure of more general poverty. Interestingly, we find that total government expenditure has no effect on World Bank aid allocation but spending on education sector does. In fact, the effects are substantially large and is significantly different from zero at the $1 \%$ level across the models in Table 1-3. This is expected as World Bank aid would supplement the government's spending on education sector specially in the needy areas.

\footnotetext{
${ }^{95}$ Dreher, Nunnenkamp and Thiele 2008.

${ }^{96}$ Nunnenkamp,Öhler and Andrés 2016.
} 
Table 3: Partisanship and World Bank education aid allocation

\begin{tabular}{|c|c|c|c|c|}
\hline & (1) & (2) & (3) & (4) \\
\hline & WB Aid (ln) & WB Aid (ln) & WB Aid (ln) & WB Aid (ln) \\
\hline \multirow[t]{2}{*}{ SC MPs X Political affiliation } & $6.817^{* * *}$ & $8.136^{* * *}$ & & \\
\hline & $(0.971)$ & $(0.989)$ & & \\
\hline \multirow[t]{2}{*}{ SC MPs X (1 - Political affiliation) } & -0.774 & -0.701 & & \\
\hline & $(1.195)$ & $(1.006)$ & & \\
\hline \multirow[t]{2}{*}{ Political affiliation } & $-6.102 * * *$ & $-7.158 * * *$ & & \\
\hline & $(2.085)$ & $(1.943)$ & & \\
\hline \multirow[t]{2}{*}{ SC Population share (Current) } & $0.159^{*}$ & 0.138 & & \\
\hline & $(0.0943)$ & $(0.0943)$ & & \\
\hline \multirow[t]{2}{*}{ SC Population share (Past) } & $0.175^{*}$ & 0.0745 & & \\
\hline & $(0.0915)$ & $(0.0904)$ & & \\
\hline \multirow[t]{2}{*}{ ST MPs X Political affiliation } & & & $5.994^{* * *}$ & $5.088^{* * *}$ \\
\hline & & & $(1.713)$ & $(1.382)$ \\
\hline \multirow[t]{2}{*}{ ST MPs X (1 - Political affiliation) } & & & 1.081 & 0.811 \\
\hline & & & $(1.577)$ & $(1.537)$ \\
\hline \multirow[t]{2}{*}{ ST Population share (Current) } & & & $-0.0821^{* *}$ & -0.0425 \\
\hline & & & $(0.0400)$ & $(0.0426)$ \\
\hline \multirow[t]{2}{*}{ ST Population share (Past) } & & & 0.000201 & 0.00887 \\
\hline & & & $(0.0419)$ & $(0.0403)$ \\
\hline \multirow[t]{2}{*}{ Political affiliation } & & & -1.084 & -3.861 \\
\hline & & & $(3.246)$ & $(2.904)$ \\
\hline \multirow[t]{2}{*}{ Population (log) } & & 0.148 & & 0.129 \\
\hline & & $(0.576)$ & & $(0.611)$ \\
\hline \multirow[t]{2}{*}{ Rural Population share } & & 4.341 & & 5.026 \\
\hline & & $(3.407)$ & & $(3.422)$ \\
\hline \multirow[t]{2}{*}{ Literacy Rate } & & $-0.167^{* * *}$ & & $-0.169 * * *$ \\
\hline & & $(0.0347)$ & & $(0.0354)$ \\
\hline \multirow[t]{2}{*}{ Elementary Education Expenditure (log) } & & $3.867^{* * *}$ & & $3.613^{* * *}$ \\
\hline & & $(0.989)$ & & $(0.961)$ \\
\hline \multirow[t]{2}{*}{ Government Expenditure (log) } & & -1.429 & & -0.682 \\
\hline & & $(1.149)$ & & $(1.173)$ \\
\hline \multirow[t]{2}{*}{ Night Light (log) } & & $-0.190^{*}$ & & -0.156 \\
\hline & & $(0.109)$ & & $(0.104)$ \\
\hline \multirow[t]{2}{*}{ Distance to State Capital (log) } & & -0.221 & & -0.301 \\
\hline & & $(0.429)$ & & $(0.466)$ \\
\hline \multirow[t]{2}{*}{ Constant } & $3.720^{* * *}$ & $-15.75^{* *}$ & $9.545^{* * *}$ & $-15.77^{*}$ \\
\hline & $(0.652)$ & $(6.906)$ & $(0.470)$ & $(9.080)$ \\
\hline Total Observations & 595 & 544 & 595 & 544 \\
\hline Estimator & OLS & OLS & OLS & OLS \\
\hline Number of States & 29 & 29 & 29 & 29 \\
\hline Number of Districts & 595 & 544 & 595 & 544 \\
\hline R-squared & 0.095 & 0.281 & 0.051 & 0.253 \\
\hline
\end{tabular}

Notes: Robust standard errors in parenthesis; Statistical significance: ${ }^{* * *} p<0.01$,

${ }^{* *} p<0.05,{ }^{*} p<0.1$ 


\subsection{Robustness checks}

We subject our main findings to a number of robustness checks, full tables of which can be found in the supplemental online appendix. First, we examine the determinants of selection of districts by the Bank using a probit estimator. In other words, we test if SC and ST MPs and their political affiliation determine the selection of districts in the gate keeping stage. Our results suggest that districts represented by ST MPs are more likely to be selected by the Bank. However, the likelihood of a district selected for World Bank aid is determined by the political affiliation of their SC and ST MPs to the party in central government.

Second, as seen in Map 1 above, some states tend to have a higher proportion of SC and ST MPs compared to others. We therefore include a dummy for those states where representation of SC and ST MPs is very high. Replicating the baseline models using the specific state dummies does not alter our results.

Third, we test whether our results hold when we estimate our baseline models with the amount of aid provided by the World Bank to a district with Poisson Pseudo Maximum Likelihood (PPML). In this instance, we give the value of zero to those districts for which no aid was allocated by the World Bank. We build on Nunnenkamp et al. and Santos Silva, who found that PPML method outperforms OLS estimator with heteroskedasticity problem and with the presence of zero observations in the data. ${ }^{97}$ The results estimated using PPML estimator are in line with our previous findings. Fourth, we use World Bank aid per capita (log) as an alternative way to operationalize our dependent variable. Our results remain robust to using a per capita measure of World Bank aid.

Fifth, we estimate all our models by excluding outliers in our dependent variable, i.e., World Bank aid. Excluding the outliers from the sample does not change our main results. This suggests that our results are not driven by outliers in the World Bank aid variable. Second, when dealing with the data on SC and ST population in India, it is noteworthy that some states (and districts) have unusually higher percentage of SC and ST population respectively and hence it is plausible that our results could be driven by the inclusion of these states into the sample. We estimate our models by dropping one state at a time from our models. Our results remain robust when we drop one state at a time from our models.

Finally, we are conscious of not overfitting our regression models. To address this problem, we adopt two approaches. First, we drop all controls which are statistically insignificant in our models, retaining only those controls which

${ }^{97}$ Nunnenkamp,Öhler and Andrés 2016; Silva, Tenreyro 2006. 
are statistically significant. Second, we re-estimate all our models dropping one control variable at a time. ${ }^{98}$ The basic results are not affected when we drop the variables which are statistically insignificant. Overall, these findings suggest that our results are robust not only to the size of the sample and alternative methods of operationalization of our main variable of interest but also to alternative estimation techniques.

\section{Conclusion and Discussion}

In this paper we have shed further light on the politics of subnational aid allocation. Notably, we have shifted the focus from the supply side of aid allocation to the dynamics of recipient demand. We've argued that marginalized constituencies, above and beyond the general poor, may be able to influence aid allocation, especially if they are politically empowered. Our findings give varying levels of support to these contentions. While there is some evidence that areas with high proportions of marginalized constituencies - in our case scheduled castes and tribes in India - receive World Bank education aid above and beyond what we might expect if allocation was based on general measures of need, there is strong and robust support that when these groups are politically empowered they receive significantly more aid. Notably, if an Indian district is represented by a SC/ST member of parliament who is aligned with the governing party, they receive up to $800 \%$ more education aid from the World Bank compared to districts not represented by an SC/ST MP aligned with the government.

This finding has two implications for the broader aid allocation literature. First, in line with theories of multilateral donors with sufficient "agency slack", we see that the World Bank is able to match action to rhetoric and target its assistance to localities with disadvantaged populations, as characterized be social marginalization above and beyond measures of poverty. These findings are consistent with literature that suggests that the World Bank considers the education rights of the minority in the process of policymaking (Chauhan 2008; Waughray 2010; Zachariah 1972)..$^{99}$

However, our findings also suggest that the agency of the marginalized population can also influence allocation behavior. Otherwise marginalized constituencies that can "speak for themselves", via representation in government, can influence aid allocation behavior. We argue that this might

\footnotetext{
${ }^{98}$ Note that we also use Area Under Curve (AUC) to gauge the predictive power of the variables in the models by dropping one variable at a time to analyze the effect on the model's fit. We find most of our variables have good predictive power.

${ }^{99}$ Zachariah 1972; Chauhan 2008; Waughray 2010.
} 
happen for several reasons, including the ability to reduce search and transaction costs, by facilitating donor access, and by providing donors with input and output legitimacy.

These findings broaden our understanding of how international, multilateral, donors interact with both national and subnational actors in recipient countries. However, they also sound a cautionary note. If sub-national aid allocation depends on the (relative) empowerment of needy communities then the "squeaky wheels" may "get the grease" while the most marginalized continue to be overlooked. 


\section{References}

Abbott, K. W., \& Snidal, D. 1998. Why states act through formal international organizations. Journal of conflict resolution, 42(1), 3-32.

Abdulai, Abdul-Gafaru and David Hulme. 2015. The Politics of Regional Inequality in Ghana: State Elites, Donors and PRSPs. Development Policy Review 33 (5): 529-553.

Achen, Christopher H. 2005. Let's Put Garbage-Can Regressions and Garbage-Can Probits Where They Belong. Conflict Management and Peace Science 22 (4): 327-329.

AidData. 2017. WorldBank_Geocoded ResearchRelease_Level1_v1.4.2 geocoded dataset. Williamsburg, VA and Washington, DC: AidData. Available at <http://aiddata.org/research-datasets> Accessed on 20 January 2018.

Aidt Toke S. and Raphael Franck. 2015. Democratization Under the Threat of Revolution: Evidence from the Great Reform Act of 1832. Econometrica 83 (2): 505-547.

Albertus, Michael. 2015. The Role of Subnational Politicians in Distributive Politics: Political

Bias in Venezuela's Land Reform Under Chávez. Comparative Political Studies 48(13) : 1667-1710.

Alesina, Alberto and David Dollar. 2000. Who Gives Foreign Aid to Whom and Why? Journal of Economic Growth 5(1): 33-63.

Ambedkar, B.R. 2014. Annihilation of Caste: The Annotated Critical Edition. VERSO.

Arbia, Ali and Gilles Carbonnier. 2016. Human Nature and Development Aid: IR and the Biology of Altruism. Journal of International Relations and Development 19(3):312-332.

Baldacci Emanuele, Benefict Clements, Sanjeev Gupta and Qiang Cui. 2004. Social Spending, Human Capital and Growth in Developing Countries: Implications for Achieving the MDGs. IMF Working Paper Available at < https://www.imf.org/external/pubs/ft/wp/2004/wp04217.pdf> Accessed on 10 January 2018.

Bardhan, P. and Mookherjee, D. 2006. Decentralisation and Accountability in Infrastructure Delivery in Developing Countries. The Economic Journal 116: 101-127.

Barrett, Sam. 2015. Subnational Adaptation Finance Allocation: Comparing Decentralized and Devolved Political Institutions in Kenya. Global Environmental Politics 15(2):118-139.

Bermeo, Sarah B. 2017. Aid Allocation and Targeted Development in an Increasingly Connected World. International Organization 71(04): 735-766.

Berthélemy, Jean-Claude. 2006. Bilateral Donors' Interest vs. Recipients' 
Development Motives in Aid Allocation: Do All Donors Behave the Same? Review of Development Economics10(2): 179-194.

Bezerra, Paul and Alex Brainthwaite. 2016. Locating Foreign Aid Commitments in Response to Political Violence. Public Choice 169: 333-355.

Bohnke, Jan R and Christoph Zurcher. 2013. Aid, Minds and Hearts: The Imact of Aid in Conflict Zones. Conflict Management and Peace Science 30(5): 411432.

Borooah, Vani K. 2012. Social Identity and Educational Attainment: The Role of Caste and Religion in Explaining Differences between Children in India. Journal of Development Studies 48(7): 887-903.

Borooah, Vani K. and Sriya Iyer. 2007. Vidya, Veda, and Varna: The influence of religion and caste on education in rural India. Journal of Development Studies 41(8): 1369-1404.

Brazys, Samuel. 2013. Evidencing Donor Heterogeity in Aid for Trade. Review of International Political Economy 20 (4): 947-978.

Briggs, Ryan C. 2014. Aiding and Abetting: Project Aid and Ethnic Politics in Kenya. World Development 64:194-205.

. 2017. Does Foreign Aid Target the Poorest? International Organization 71(1): 187-206.

Carter, Patrick. 2014. Aid Allocation Rules. European Economic Review 71: 132151.

Chaturvedi, Ruchi. 2011. Somehow It Happened: Violence, Culpability and the Hindu Nationalist Community. Cultural Anthropology 26 (3): 340-362.

Chauhan, Chandra P.S. 2007. Education and Caste in India. Asia Pacific Journal of Education 28(3): 217-234.

Chin Aimee and Nishith Prakash. 2011. The Redistributive Effects of Political Reservation for Minorities: Evidence from India. Journal of Development Economics 96 (2) : 265-277.

Claessens, Stijn, Danny Cassimon and Bjorn Van Campenhout. 2009. Evidence on changes in aid allocation criteria. World Bank Economic Review 23(2): 185208.

Clist, Paul, Alessia Isopi and Oliver Morrisey. 2012.Selectivity on Aid Modality: Determinants of Budget Support From Multilateral Donors. Review of International Organizations 7(3): 267-284.

Colclough,Christopher and Anuradha De. 2010. The impact of aid on education policy in India. International Journal of Educational Development 30(5): 497-507.

Copelovitch, Mark S. 2010. Master or servant? Common agency and the political economy of IMF lending. International Studies Quarterly 54(1): 49-77.

Cremin, Peadar and Mary Goretti Nakabugo. 2012. Education, Development and 
Poverty Reduction: A Literature Critique. International Journal of Educational Development 32(4): 499-506.

D'Aiglepierre, Rohen and Laurent Wagner. 2013. Aid and Universal Primary

Education. Economics of Education Review (37): 95-112.

Deshpande Ashwini and Katherine Newman. 2007. Where the Path Leads: The Role of Caste

in Post-University Employment Expectations. Economic and Political Weekly 42 (41): 4133-4140.

Dietrich, Simone. 2013. Bypass or Engage? Explaining Donor Delivery Tactics in Foreign Aid Allocation. International Studies Quarterly 57(4): 698-712.

Dietrich, Simone and Joseph Wright. 2015. Foreign Aid Allocation Tactics and Democratic Change in Africa. The Journal of Politics 77(1): 216-234.

Dollar David and Victoria Levin. 2006. The Increasing Selectivity of Foreign Aid, 1984-2003. World Development 34 (12): 2034-2046.

Dreher, Axel and Nathan M. Jensen. 2007. Indepedent Actor or Agent? An

Emperical Analysis of the Impact of U. S. Interests on International Monetary Fund Conditions. The Journal of Law and Economics 50(1): 105124.

Dreher, A., Sturm, J. E., \& Vreeland, J. R. (2009). Development aid and international

politics: Does membership on the UN Security Council influence World Bank decisions?. Journal of Development Economics, 88(1), 1-18.

Dreher, Alex, Peter Nunnenkamp and Rainer Thiele. 2008. Does aid for education educate children? Evidence from panel data. The World Bank Economic Review 22(2): 291-314.

Dreher, Axel, Sarah Langlotz and Silvia Marchesi. 2017.Information transmission and ownership consolidation in aid programs. Economic Inquiry 55(4): 16711688.

Dunn, Dana. 1993. Gender Inequality in Education and Employment in the Scheduled Castes and Tribes of India. Population Research and Policy Review 12(1): 53-70.

Eichenauer, Vera Z. and Simon Hug. 2018. The Politics of Special Purpose Trust Funds. Economics and Politics 30 (2): 211-255.

Eichenauer, Vera Z. and Bernhard Reinsberg. 2017. What Determines Earmarked Funding to International Development Organizations? Evidence from the New Multi-Bi Aid Data. Review of International Organizations 12(2): 171197.

Fang, S., \& Stone, R. W. 2012. International organizations as policy advisors. International

Organization, 66(4), 537-569. 
Faure, Edgar, Felipe Herrera, Abdul-Razzak Kaddoura, Henri Lopes, Arthur V. Petrovsky, Majid rahnea and Frderick C. Ward. 1972. The world of education today and tomorrow. UNESCO. Available at <http://unesdoc.unesco.org/images/0000/000018/001801e.pdf.> Accessed on 10 January 2018.

Filmer Deon and Lant H. Pritchett. 2001. Estimating Wealth Effects Without Expenditure Data--Or Tears: An Application to Educational Enrolments in States of India. Demography 38 (1): 115-132.

Findley, Michael G, Josh Powell, Daniel Strandow and Jeff Tanner. 2011. The Localized Geography of Foreign Aid: A Nw Dataset and Application to Violent Armed Conflict. World Development 39(11):1995-2009.

Fleck, Robert K. and Christopher Kilby. 2016. World Bank Independence: A Model and Statistical Analysis of US Influence. Review of Development Economics 10(2): 224-240.

Galasso, Emanuela and Ravallion, Martin. 2005. Decentralized targeting of an antipoverty program. Journal of Public Economics 89(4): 705-727.

Government of India. 2018. National Family Health Survey 2015-2016 Available at < http://microdata.worldbank.org/index.php/catalog/2949>Accessed on 20 January 2018.

Gehring, Kai, Florian Kauffeldt and Krishna Chaitanya Valamannati. 2018. Crime, Incntives and Political Effort: A Model and Empirical Application for India. European Journal of Political Economy. Forthcoming.

Gupta, Sanjeev, Marijn Verhoeven and Erwin Tiongson. 1999. Does Higher Government Spending Buy Better Reults in Education and Health Care? International Monetary Fund Working Paper Available at < https://www-imf org.ucd.idm.oclc.org/external/pubs/ft/wp/1999/wp9921.pdf> Accessed on 20 January 2018.

Haan, Arjan de. Social Exclusion: Towards An Holistic Understanding of Deprivation. Department for International Development UK January 1999. Available at $\quad<\quad$ https://www-imforg.ucd.idm.oclc.org/external/pubs/ft/wp/1999/wp9921.pdf > Accssed on 20 January 2018.

Halim, Nafisa, Kathryn M. Yount and Solveig Cunningham. 2016. Do Scheduled Caste and Scheduled Tribe Women Legislators Mean Lower Gender Caste Gaps in Primary Schooling in India? Social Science Research 58: 122-134.

Henderson, Vernon J., Adam Storeygard and David N. Weil. Measuring Economic Growth from Outer Space. American Economic Review 102 (2): 994-1028.

Hoeffler, Anke and Verity Outram. 2011. Need, Merit or Self-Interest-What Determines the Allocation of Aid? Review of Development Economics 15(2): 237-250. 
Hoff, Karla. 2016. Caste System. World Bank Policy Research Paper 7929.

Available at

<https://openknowledge.worldbank.org/bitstream/handle/10986/25832/W

PS7929.pdf?sequence=1\&isAllowed=y $>$ Accessed on 10 January 2018.

Hoff, Karla, Priyanka Pandey. 2011. Making Up People-The Behavioral Effects of Caste. World Bank Policy Research Paper. September 2011. Available at < http://siteresources.worldbank.org/DEC/Resources/NewVersionHoffPandey makinguppeoplethebehavioraleffectsofcastetext.pdf> Accessed on 10 January 2018.

Howard, Larry L. and Nishith Prakash. 2011. Do School Lunch Subsides Change the Dietary Patterns of Children From Low-Income Households? Contemporary Economic Policy 30 (3): 362-381.

Humphrey, Chris and Katharina Michaelowa. 2013. Shopping for Development: Multilateral Lending, Shareholder Composition and Borrower Preferences. World Development 44: 142-155.

IDSN. 2010. Caste Systems Obstruct South Asian Education. 27 January. Available at $\quad<$ https://idsn.org/caste-systems-obstruct-south-asian-education/> Accessed on 10 October 2018.

Jablonski, Ryan S. 2014. How Aid Targets Votes : The Impact of Electorial Incentives on Foreign Aid Distribution. World Politics 66 (2): 293-330.

Khemani, Stuti. 2007. Party Politics and Fiscal Discipline in A Federation: Evidence from the States of India. Comparative Political Studies. 40 (6): 691-712.

Lum, Thomas, Hannah Fischer, Julissa Gomez-Granger and Anne Leland. 2009. China's Foreign Aid Activities in Africa, Latin America, and Southeast Asia, Congressional Research Service Report R40361.

Malik, R., \& Stone, R. W. (2015, February). Private Politics in World Bank Lending. Political Economy of International Organization Conference, Berlin, Germany. Martens, Bertin. 2005. Why do aid agencies exist?. Development policy review 23(6): 643-663.

Milner, Helen V. and Dustin Tingley. 2013. The Choice for Multilateralism: Foreign Aid and American Foreign Policy. Review of International Organizations 8(3): 313-341.

Nair,Padmaja .2007. Whose Public Action? Analyzing Inter-sectoral Collaboration for Service

Delivery: Identification of Programmes for Study in India. International Development Department UK Economic and Social Research Council: University if Birmingham.

Neumayer, E., 2003. The Determinants of Aid Allocation by Regional Multilateral Development Banks and United Nations Agencies. International Studies Quarterly, 47(1), pp.101-122. 
Nielson, Daniel L. and Michael J. Tierney. 2003. Delegation to international organizations: Agency theory and World Bank environmental reform. International organization 57(2): 241-276.

Novelli, Mario. 2010. The New Geopolitics of Educational Aid: From Cold Wars to Holy Wars? International Journal of Educational Development 30(5): 453459.

Nunnenkamp, Peter, Hannes Öhler and Maximiliano Sosa Andrés. 2017. Need, Merit and Politics in Multilateral Aid Allocation: A District-level Analysis of World Bank Projects in India. Review of Development Economics 21(1): 126-156.

Nussbaum, Martha C. 2011. Creating capabilities: The human development approach. Boston, MA: Harvard University Press.

Oestreich, Joel E. 2004. The Human Rights Responsibilities of the World Bank. Global Social Policy 4(1): 55-76.

Öhler, Hannes and Peter Nunnenkamp. 2014. Needs-based targeting or favoritism? The regional allocation of multilateral aid within recipient countries. Kyklos 67(3): 420-446.

Omprasad, Gadde. 2016. From Project Based Lending to Ppolicy Based Lending: An Evaluation of Structural Adjustment Lending Policy of World Bank. Journal of Social and Administrative Sciences 3(1): 268-281.

Pande, Rohini. 2003. Can Mandated Political Representation Increase Policy Influence for Disadvantaged Minorities? Theory and Evidence from India. American Economic Review 93 (4): 1132-1151.

Pellissery, Sony, Amrutha Jose Pampackal and Partha Bopaiah. 2015. Caste and Distributive Justice: Can Social Policy Address Durable Inequalities? Social Policy and Administration 49(6): 785-800.

Radelet, Steven. 2006. Primer on Foreign Aid. Working Paper 92. Washington DC: Center of Global Development.

Rahman, Md. S. and Lukas Giessen. 2017. Formal and Informal Interests of Donors to Allocate Aid: Spending Patterns of USAID, GIZ, and EU Forest Development Policy in Bangladesh. World Development 94: 250-267.

Reinhardt, Gina Y. 2006. Shortcuts and Signals: An Analysis of the Microlevel Determinants of Aid Allocation, with Case Study Evidence from Brazil. Review of Development Economics10(2): 297-312.

Roberts John. 2003. Poverty Reduction Outcomes in Education and Health: Public Expenditure and Aid. ODI Working Paper 210, Overseas Development Institute: London.

Scaria, Suma. 2014. Do Caste and Class Define Inequality? Revisiting Education in a Kerala Village. Contemporary Education Dialogue 11(2): 153-177.

Schneider, Christina J. and Jennifer L. Tobin. 2013. Interest Coalitions and Multilateral Aid Allocation in the EUropean Union. International Studies 
Quarterly 57(1): 103-114.

Sen, Amartya. 1999. Development as Freedom. Oxford: Oxford University Press.

Silva, J.M.C. Santos and Silvana Tenreyro. 2006. The Log of Gravity. The Review of Economics and Statistics 88 (4): 641-658.

Social and Rural Research Institute. 2014. National Sample Survey of Estimation of Out -of-School Children in the Age 6- 13 in India. Avaiable at <http://eldis.org/organisation/A5878> Accessed on 10 January 2018.

Stubbs, Thomas H., Alexander E. Kentikelenis and Lawrence P. King. 2016. Catalyzing Aid? The IMF and Donor Behavior in Aid Allocation. World Development 78:511-528.

Sujatha, Gothoskar. 2000. Teleworking and Gender: Emerging Issues. Economic and Political Weekly 35 (26): 2293-2298.

Swedlund, Haley J. 2017a. Can Foreign Aid Donors Credibly Threaten to Suspend Aid? Evidence from A Cross-National Survey of Donor Officials. Review of International Political Economy 24(3): pp.454-496.

. 2017b. The Development Dance: How Donors and Recipients Negotiate the Delivery of Foreign Aid. Ithaca, NY: Cornell University Press.

The Government of India. 1950. The Constitution of India. Available at: $<$ https://www.india.gov.in/my-government/constitution-india> Accessed on March 30, 2018

The Times of India. 2015. India Bright Spot in Global Economy; Caste Bias a Concern: World Bank. 11 Jan 2015 Available at < https://timesofindia.indiatimes.com/india/India-bright-spot-in-globaleconomy-caste-bias-a-concern-World-Bank/articleshow/45843719.cms> Accessed on 10 April 2018.

The World Bank. 2011. Poverty and Social Exclusion in India. Available at <https://openknowledge.worldbank.org/handle/10986/2289> Accessed on April 10, 2018

Thiele, Rainer, Peter Nunnenkamp and Axel Dreher. 2007. Do donors target aid in line with the millennium development goals? A sector perspective of aid allocation. Review of World Economics 143(4): 596-630.

Tilak, Jandhyala B.G. 1979. Inequality in Education in India. Indian Journal of Industrial Relations 14(3): 417-436.

. 2008. Political economy of external aid for education in India. Journal of Asian Public Policy 1(1): 32-51.

United Nations. 1998. Universal Declaration of Human Rights. Avaiable at < http://www.un.org/en/universal-declaration-human-rights/>. Accessed on 10 April 2018.

Vadlamannati, Krishna C. 2011. Why Indian Men Rebel? Explaining Armed Rebellion in the Northeastern States of India, 1970-2007. Journal of Peace 
Research 48 (5): 605-619.

2016. Fighting Corruption or Elections? The Politics of

Anti-corruption Policies in India: A Subnational Study. Journal of Comparative Economics 43(4): 1035-1052.

Waughray, Annapurna. 2010. Caste discrimination and minority rights: The case of India's dalits. International Journal on Minority and Group Rights 17(2): 327-353.

Wiggins, Jackie. 1999. Teacher Control and Creativity. Music Educators Journal 85 (5): 30-44.

Winters, Matthew S.2010. Choosing to target: What types of countries get different types of World Bank projects. World Politics 62(3): 422-458. .2010.Accountaility, Participation and Foreign Aid Effectiveness. International Studies Review 12 (2): 218-243.

Younas, Javed. 2008. Motivation for Bilateral Aid Allocation: Altruism or Trade Benefits. European Journal of Political Economy 24(3): 661-674.

Zachariah, Mathew. 1972. Positive Discrimination in Education for India's Scheduled Castes: A Review of the Problems, 1950-1970. Comparative Education Review 16 (1): 16-29.

Zhang, Guang. 2004. The Determinants of Foreign Aid Allocation across China: The Case of World Bank Loans. Asian Survey 44 (5): 691-710.

Zyck, Steven A. 2012. How to Lose Allies and Finance Your Enemies: The Economisation of Conflict Termination in Afghanistan. Conflict, Security \& Development 12(3):249-271. 


\section{Appendix}

Appendix 1: List of States

\begin{tabular}{lllll}
\hline Andhra Pradesh & Dadra \& Nagar Haveli* & Jammu \& Kashmir & Manipur & Rajasthan \\
Andaman \& Nicobar Islands* & Daman \& Diu* & Jharkhand & Meghalaya & Sikkim \\
Arunachal Pradesh & Delhi* & Karnataka & Mizoram & Tamil Nadu \\
Assam & Goa & Kerala & Nagaland & Tripura \\
Bihar & Gujarat & Lakshadweep* & Orissa & Uttar Pradesh \\
Chandigarh* & Haryana & Madhya Pradesh & Pondicherry* & Uttaranchal \\
Chhattisgarh & Himachal Pradesh & Maharashtra & Punjab & West Bengal \\
\hline
\end{tabular}

* denote Union Territories which are administrative divisions and are ruled directly by Government of India.

Appendix 2: Descriptive Statistics

\begin{tabular}{lccccc}
\hline \multicolumn{1}{c}{ Variables } & Mean & Standard Deviation & Minimum & Maximum Observations \\
\hline World Bank Education Aid (log) & 7.630 & 9.498 & 0.00 & 20.47 & 682 \\
SC District Population Share & 14.644 & 8.710 & 0.00 & 50.11 & 597 \\
ST District Population Share & 14.204 & 8.896 & 0.00 & 53.40 & 596 \\
SC District Population Share Census & 16.405 & 26.011 & 0.00 & 98.09 & 597 \\
ST District Population Share Census & 16.209 & 25.944 & 0.00 & 98.42 & 596 \\
SC MPs & 0.218 & 0.464 & 0.00 & 3.00 & 682 \\
ST MPs & 0.147 & 0.386 & 0.00 & 3.00 & 682 \\
Total District Population (log) & 13.982 & 1.032 & 10.35 & 17.73 & 593 \\
Rural Population share & 0.767 & 0.188 & 0.00 & 1.00 & 618 \\
District Night light satellite images (log) & 5.125 & 7.276 & 0.00 & 63.00 & 672 \\
District Literacy Rate & 63.945 & 12.871 & 30.17 & 96.51 & 586 \\
Elementary Education Expenditure (log) & 10.448 & 1.161 & 5.21 & 11.84 & 682 \\
Total Government Expenditure (log) & 8.600 & 0.937 & 6.28 & 9.78 & 670 \\
Distance to State Capital (log) & 5.008 & 0.949 & 0.00 & 7.22 & 653 \\
\hline
\end{tabular}


Appendix 3: Data Definition and Sources

Variable

\begin{tabular}{|c|c|}
\hline Variable & Data definition and sources \\
\hline World Bank Education Aid (log) & $\begin{array}{l}\text { World Bank education aid measured in US\$ constant prices (logged). The } \\
\text { data at district level is sourced from the World Bank Geocoded Aid Data } \\
\text { v1.4.2 from AidData for the 1996, 1997, 1998, 1999, } 2001 \text { rounds. }\end{array}$ \\
\hline SC District Population Share & $\begin{array}{l}\text { The data on SC population/Total Population district-wise is sourced from the } \\
\text { Census of India, } 2001 .\end{array}$ \\
\hline ST District Population Share & $\begin{array}{l}\text { The data on ST population/Total Population district-wise is sourced from the } \\
\text { Census of India, } 2001 .\end{array}$ \\
\hline SCMPs & $\begin{array}{l}\text { Number of SC MPs elected from SC constituencies is mapped on geographic } \\
\text { districts during the } 2001 \text { period }\end{array}$ \\
\hline ST MPs & $\begin{array}{l}\text { Number of ST MPs elected from ST constituencies is mapped on geographic } \\
\text { districts during the } 2001 \text { period }\end{array}$ \\
\hline Total District Population (log) & We access district-wise total population from the Census of India 2001. \\
\hline Rural Population & $\begin{array}{l}\text { Rural population as a share of total population sourced from the Census of } \\
\text { India } 2001 .\end{array}$ \\
\hline District Literacy Rate & $\begin{array}{l}\text { Male and female Literacy rate of district-wise sourced from the Census of } \\
\text { India } 2001 .\end{array}$ \\
\hline $\begin{array}{l}\text { Elementary Education } \\
\text { Expenditure (log) }\end{array}$ & $\begin{array}{l}\text { Government expenditure on elementary education refers to actual } \\
\text { expenditure on elementary education at the state level for the period 1991- } \\
2001 \text { which is sourced from the https://www.indiastat.com. }\end{array}$ \\
\hline Government Expenditure (log) & $\begin{array}{l}\text { Total government expenditure includes capital expenditure and revenue } \\
\text { expenditure for the period 1991-2001 sourced from the Reserve Bank of } \\
\text { India. }\end{array}$ \\
\hline Distance to State Capital (log) & $\begin{array}{l}\text { Distance to capital means the distance from specific district to capital of } \\
\text { state (straight line distance). We applied distance calculator to figure them } \\
\text { out. It can be found at https://www.distancefromto.net. }\end{array}$ \\
\hline
\end{tabular}


SUPPLEMENTAL ONLINE APPENDIX

TABLES ON ROBUSTNESS CHECKS 
Table A1: Probability of securing World Bank education aid and SC, ST population share

\begin{tabular}{lccc}
\hline & $\mathbf{( 1 )}$ & $\mathbf{( 2 )}$ & $\mathbf{( 3 )}$ \\
& $p$ (WB Aid) & $p$ (WB Aid) & $p$ (WB Aid) \\
\hline SC Population share (Current) & $0.0330^{* *}$ & & $0.0374^{* *}$ \\
& $(0.0141)$ & & $(0.0153)$ \\
ST Population share (Current) & & -0.00666 & 0.000403 \\
SC Population share (Past) & & $(0.00772)$ & $(0.00830)$ \\
& 0.0110 & & 0.0114 \\
ST Population share (Past) & $(0.0142)$ & & $(0.0145)$ \\
& & 0.000382 & 0.00330 \\
Population (log) & & $(0.00719)$ & $(0.00771)$ \\
& 0.117 & 0.0954 & 0.137 \\
Rural Population share & $(0.109)$ & $(0.109)$ & $(0.112)$ \\
Literacy Rate & 0.852 & $1.074^{*}$ & 0.860 \\
& $(0.663)$ & $(0.629)$ & $(0.667)$ \\
Elementary Education Expenditure (log) & $\left(0.610^{* * *}\right.$ & $0.618^{* * *}$ & $0.623^{* * *}$ \\
Government Expenditure (log) & $(0.179)$ & $(0.175)$ & $(0.180)$ \\
Night Light (log) & -0.130 & -0.101 & -0.123 \\
& $(0.198)$ & $(0.194)$ & $(0.202)$ \\
Distance to State Capital (log) & $-0.0620^{* *}$ & $-0.0427^{*}$ & $-0.0614^{* *}$ \\
Constant & $(0.0277)$ & $(0.0245)$ & $(0.0281)$ \\
& 0.0251 & 0.0161 & 0.0166 \\
Total Observations & $(0.0900)$ & $(0.0865)$ & $(0.0914)$ \\
Number of States & $-6.902^{* * *}$ & $-6.240^{* * *}$ & $-7.547^{* * *}$ \\
Number of Districts & $(1.487)$ & $(1.648)$ & $(1.732)$ \\
\hline
\end{tabular}

Notes: Reports coefficients

Robust standard errors in parenthesis

Statistical significance: ${ }^{* * *} p<0.01,{ }^{*} p<0.05,{ }^{*} p<0.1$ 
Table A2: Probability of securing World Bank education aid allocation and SC, ST MPs

\begin{tabular}{|c|c|c|c|}
\hline & (1) & (2) & (3) \\
\hline & $p$ (WB Aid) & $p$ (WB Aid) & $p$ (WB Aid) \\
\hline \multirow[t]{2}{*}{ SC MPs } & 0.102 & & 0.111 \\
\hline & $(0.138)$ & & $(0.138)$ \\
\hline \multirow[t]{2}{*}{ SC Population share (Current) } & $0.0310^{* *}$ & & $0.0346^{* *}$ \\
\hline & $(0.0142)$ & & $(0.0154)$ \\
\hline \multirow[t]{2}{*}{ SC Population share (Past) } & 0.0109 & & 0.0117 \\
\hline & $(0.0141)$ & & $(0.0144)$ \\
\hline \multirow[t]{2}{*}{ ST MPs } & & $0.319^{*}$ & $0.344^{*}$ \\
\hline & & $(0.178)$ & $(0.185)$ \\
\hline \multirow[t]{2}{*}{ ST Population share (Current) } & & -0.00966 & -0.00318 \\
\hline & & $(0.00778)$ & $(0.00830)$ \\
\hline \multirow[t]{2}{*}{ ST Population share (Past) } & & -0.000600 & 0.00235 \\
\hline & & $(0.00726)$ & $(0.00766)$ \\
\hline \multirow[t]{2}{*}{ Population (log) } & 0.115 & 0.0588 & 0.0977 \\
\hline & $(0.109)$ & $(0.114)$ & $(0.118)$ \\
\hline \multirow[t]{2}{*}{ Rural Population share } & 0.863 & 1.024 & 0.812 \\
\hline & $(0.661)$ & $(0.631)$ & $(0.667)$ \\
\hline \multirow[t]{2}{*}{ Literacy Rate } & $-0.0228^{* * *}$ & $-0.0251^{* * *}$ & $-0.0218^{* * *}$ \\
\hline & $(0.00666)$ & $(0.00662)$ & $(0.00681)$ \\
\hline \multirow[t]{2}{*}{ Elementary Education Expenditure (log) } & $0.605^{* * *}$ & $0.619^{* * *}$ & $0.621^{* * *}$ \\
\hline & $(0.180)$ & $(0.176)$ & $(0.181)$ \\
\hline \multirow[t]{2}{*}{ Government Expenditure (log) } & -0.128 & -0.0998 & -0.127 \\
\hline & $(0.199)$ & $(0.194)$ & $(0.203)$ \\
\hline \multirow[t]{2}{*}{ Night Light (log) } & $-0.0637^{* *}$ & $-0.0429^{*}$ & $-0.0637^{* *}$ \\
\hline & $(0.0282)$ & $(0.0244)$ & $(0.0285)$ \\
\hline \multirow[t]{2}{*}{ Distance to State Capital (log) } & 0.0289 & 0.00412 & 0.0103 \\
\hline & $(0.0897)$ & $(0.0865)$ & $(0.0915)$ \\
\hline \multirow[t]{2}{*}{ Constant } & $-6.853 * * *$ & $-5.638^{* * *}$ & $-6.820^{* * *}$ \\
\hline & $(1.480)$ & $(1.719)$ & $(1.811)$ \\
\hline Total Observations & 544 & 544 & 544 \\
\hline Estimator & Probit & Probit & Probit \\
\hline Number of States & 29 & 29 & 29 \\
\hline Number of Districts & 544 & 544 & 544 \\
\hline
\end{tabular}

Notes: Reports coefficients

Robust standard errors in parenthesis

Statistical significance: ${ }^{* * *} p<0.01,{ }^{* *} p<0.05,{ }^{*} p<0.1$ 
Table A3: Probability of securing World Bank education aid allocation and SC, ST MPs

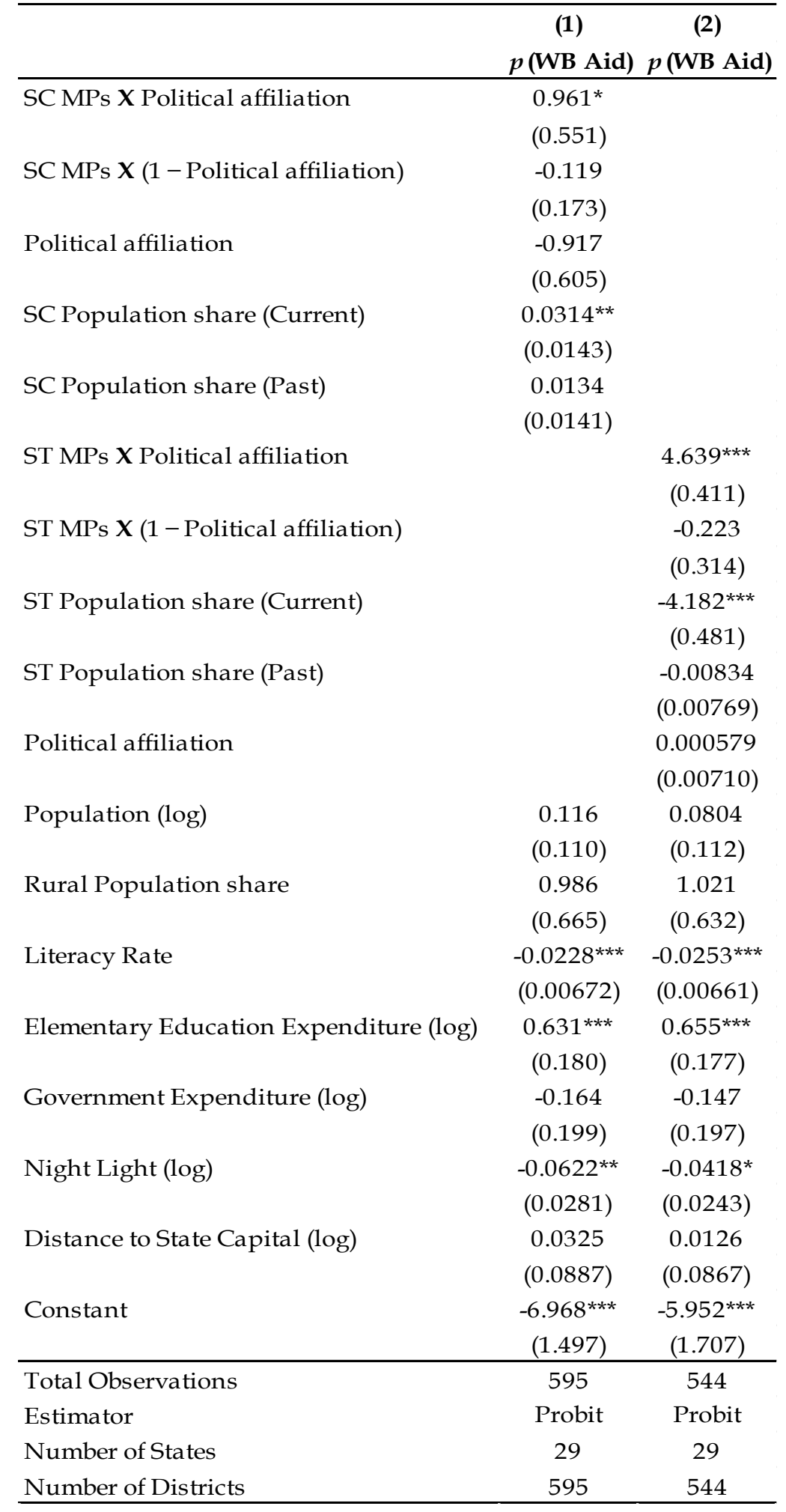

Notes: Reports coefficients

Robust standard errors in parenthesis

Statistical significance: ${ }^{* *} p<0.01,{ }^{* *} p<0.05, * p<0.1$ 
Table B1: World Bank education aid and SC, ST MPs - Difference-in-Difference

(1) (2)

(3)

(4)

WB Aid (ln) WB Aid (ln) WB Aid (ln) WB Aid (ln)

\begin{tabular}{|c|c|c|c|c|}
\hline SC MPs & & & $\begin{array}{c}7.791^{* * *} \\
(2.219)\end{array}$ & \\
\hline SC Population share (Current) & $\begin{array}{c}0.194 \\
(0.299)\end{array}$ & & $\begin{array}{l}0.0822 \\
(0.296)\end{array}$ & \\
\hline SC Population share (Past) & $\begin{array}{l}-0.196 \\
(0.181)\end{array}$ & & $\begin{array}{l}-0.101 \\
(0.184)\end{array}$ & \\
\hline ST MPs & & & & $\begin{array}{l}4.345^{* *} \\
(2.062)\end{array}$ \\
\hline ST Population share (Current) & & $\begin{array}{r}-0.0389 \\
(0.193)\end{array}$ & & $\begin{array}{r}-0.0131 \\
(0.200)\end{array}$ \\
\hline ST Population share (Past) & & $\begin{array}{l}0.0240 \\
(0.139)\end{array}$ & & $\begin{array}{c}-0.00126 \\
(0.153)\end{array}$ \\
\hline Population (log) & $\begin{array}{l}1.054 \\
(2.059)\end{array}$ & $\begin{array}{c}2.054 \\
(3.389)\end{array}$ & $\begin{array}{c}0.720 \\
(2.061)\end{array}$ & $\begin{array}{c}0.483 \\
(3.742)\end{array}$ \\
\hline Rural Population share & $\begin{array}{c}4.261 \\
(12.26)\end{array}$ & $\begin{array}{l}49.34^{* *} \\
(21.33)\end{array}$ & $\begin{array}{c}8.668 \\
(11.89)\end{array}$ & $\begin{array}{l}52.03^{* *} \\
(20.77)\end{array}$ \\
\hline Literacy Rate & $\begin{array}{l}-0.222 \\
(0.172)\end{array}$ & $\begin{array}{l}-0.217 \\
(0.180)\end{array}$ & $\begin{array}{l}-0.274 \\
(0.189)\end{array}$ & $\begin{array}{l}-0.183 \\
(0.185)\end{array}$ \\
\hline Elementary Education Expenditure (log) & $\begin{array}{l}4.601 \\
(4.831)\end{array}$ & $\begin{array}{l}-10.50 \\
(10.87)\end{array}$ & $\begin{array}{c}6.445 \\
(4.994)\end{array}$ & $\begin{array}{l}-7.089 \\
(9.864)\end{array}$ \\
\hline Government Expenditure (log) & $\begin{array}{c}1.471 \\
(4.786)\end{array}$ & $\begin{array}{c}9.652 \\
(6.056)\end{array}$ & $\begin{array}{l}-0.182 \\
(5.283)\end{array}$ & $\begin{array}{c}6.138 \\
(5.402)\end{array}$ \\
\hline Night Light (log) & $\begin{array}{c}0.00212 \\
(0.255)\end{array}$ & $\begin{array}{c}0.442 \\
(0.583)\end{array}$ & $\begin{array}{c}0.135 \\
(0.261)\end{array}$ & $\begin{array}{c}0.760 \\
(0.604)\end{array}$ \\
\hline Distance to State Capital (log) & $\begin{array}{l}-0.957 \\
(1.424)\end{array}$ & $\begin{array}{c}0.501 \\
(4.145)\end{array}$ & $\begin{array}{l}-0.705 \\
(1.191)\end{array}$ & $\begin{array}{c}0.132 \\
(3.902)\end{array}$ \\
\hline Constant & $\begin{array}{l}-51.16 \\
(40.64)\end{array}$ & $\begin{array}{l}-21.44 \\
(104.6)\end{array}$ & $\begin{array}{l}-61.03 \\
(44.88)\end{array}$ & $\begin{array}{l}-14.56 \\
(101.9)\end{array}$ \\
\hline Sample Districts & SC aligned & SC aligned & ST aligned & ST aligned \\
\hline Total Observations & 79 & 38 & 79 & 38 \\
\hline Estimator & OLS & OLS & OLS & OLS \\
\hline Number of Districts & 79 & 38 & 79 & 38 \\
\hline R-squared & 0.219 & 0.347 & 0.273 & 0.404 \\
\hline
\end{tabular}

Notes: Robust standard errors in parenthesis

Statistical significance: ${ }^{* * *} p<0.01,{ }^{*} p<0.05,{ }^{*} p<0.1$ 
Table C1: World Bank education aid and SC, ST MPs - with State specific dummies

\begin{tabular}{|c|c|c|c|c|}
\hline & (1) & (2) & (3) & (4) \\
\hline & WB Aid (ln) & WB Aid (ln) & WB Aid (ln) & WB Aid (ln) \\
\hline \multirow[t]{2}{*}{ SC MPs } & 1.075 & & & \\
\hline & $(0.798)$ & & & \\
\hline \multirow[t]{2}{*}{ ST MPs } & & $1.932^{* *}$ & & \\
\hline & & $(0.960)$ & & \\
\hline \multirow[t]{2}{*}{ SC MPs X Political affiliation } & & & $7.951^{* * *}$ & \\
\hline & & & $(1.006)$ & \\
\hline \multirow[t]{2}{*}{ SC MPs X (1 - Political affiliation) } & & & -0.724 & \\
\hline & & & $(1.009)$ & \\
\hline \multirow[t]{2}{*}{ Political affiliation } & & & $-6.952 * * *$ & \\
\hline & & & $(1.947)$ & \\
\hline \multirow[t]{2}{*}{ SC Population share (Current) } & 0.138 & & 0.136 & \\
\hline & $(0.0957)$ & & $(0.0953)$ & \\
\hline \multirow[t]{2}{*}{ SC Population share (Past) } & 0.0414 & & 0.0634 & \\
\hline & $(0.0933)$ & & $(0.0921)$ & \\
\hline \multirow[t]{2}{*}{ ST MPs X Political affiliation } & & & & $4.698^{* * *}$ \\
\hline & & & & $(1.200)$ \\
\hline \multirow[t]{2}{*}{ ST MPs X (1 - Political affiliation) } & & & & 0.505 \\
\hline & & & & $(1.566)$ \\
\hline \multirow[t]{2}{*}{ ST Population share (Current) } & & -0.0489 & & -0.0469 \\
\hline & & $(0.0431)$ & & $(0.0431)$ \\
\hline \multirow[t]{2}{*}{ ST Population share (Past) } & & 0.00439 & & 0.00588 \\
\hline & & $(0.0410)$ & & $(0.0410)$ \\
\hline \multirow[t]{2}{*}{ Political affiliation } & & & & -2.718 \\
\hline & & & & $(2.823)$ \\
\hline \multirow[t]{2}{*}{ Population (log) } & 0.166 & 0.0500 & 0.170 & 0.0524 \\
\hline & $(0.571)$ & $(0.621)$ & $(0.576)$ & $(0.619)$ \\
\hline \multirow[t]{2}{*}{ Rural Population share } & 3.637 & 4.925 & 4.421 & 4.803 \\
\hline & $(3.467)$ & $(3.421)$ & $(3.411)$ & $(3.444)$ \\
\hline \multirow[t]{2}{*}{ Literacy Rate } & $-0.173^{* * *}$ & $-0.181^{* * *}$ & $-0.171^{* * *}$ & $-0.179^{* * *}$ \\
\hline & $(0.0346)$ & $(0.0352)$ & $(0.0348)$ & $(0.0353)$ \\
\hline \multirow[t]{2}{*}{ Elementary Education Expenditure (log) } & $3.789 * * *$ & $3.866^{* * *}$ & $3.984^{* * *}$ & $3.981^{* * *}$ \\
\hline & $(1.010)$ & $(0.980)$ & $(1.002)$ & $(0.986)$ \\
\hline \multirow[t]{2}{*}{ Government Expenditure (log) } & -1.312 & -1.167 & -1.584 & -1.347 \\
\hline & $(1.165)$ & $(1.191)$ & $(1.160)$ & $(1.211)$ \\
\hline \multirow[t]{2}{*}{ Night Light (log) } & $-0.188^{*}$ & -0.146 & $-0.181^{*}$ & -0.146 \\
\hline & $(0.110)$ & $(0.105)$ & $(0.110)$ & $(0.106)$ \\
\hline \multirow[t]{2}{*}{ Distance to State Capital (log) } & -0.219 & -0.363 & -0.246 & -0.357 \\
\hline & $(0.443)$ & $(0.466)$ & $(0.432)$ & $(0.468)$ \\
\hline \multirow[t]{2}{*}{ Constant } & $-15.32^{* *}$ & -12.88 & $-15.88^{* *}$ & -12.68 \\
\hline & $(6.920)$ & $(9.130)$ & $(6.921)$ & $(9.197)$ \\
\hline Total Observations & 544 & 544 & 544 & 544 \\
\hline Estimator & OLS & OLS & OLS & OLS \\
\hline States Dummy & Yes & Yes & Yes & Yes \\
\hline Number of States & 29 & 29 & 29 & 29 \\
\hline Number of Districts & 544 & 544 & 544 & 544 \\
\hline R-squared & 0.276 & 0.259 & 0.287 & 0.262 \\
\hline
\end{tabular}

Notes: Robust standard errors in parenthesis

Statistical significance: $* * * p<0.01, * * p<0.05, * p<0.1$ 
Table D1: World Bank education aid and SC, ST MPs - Poisson estimates

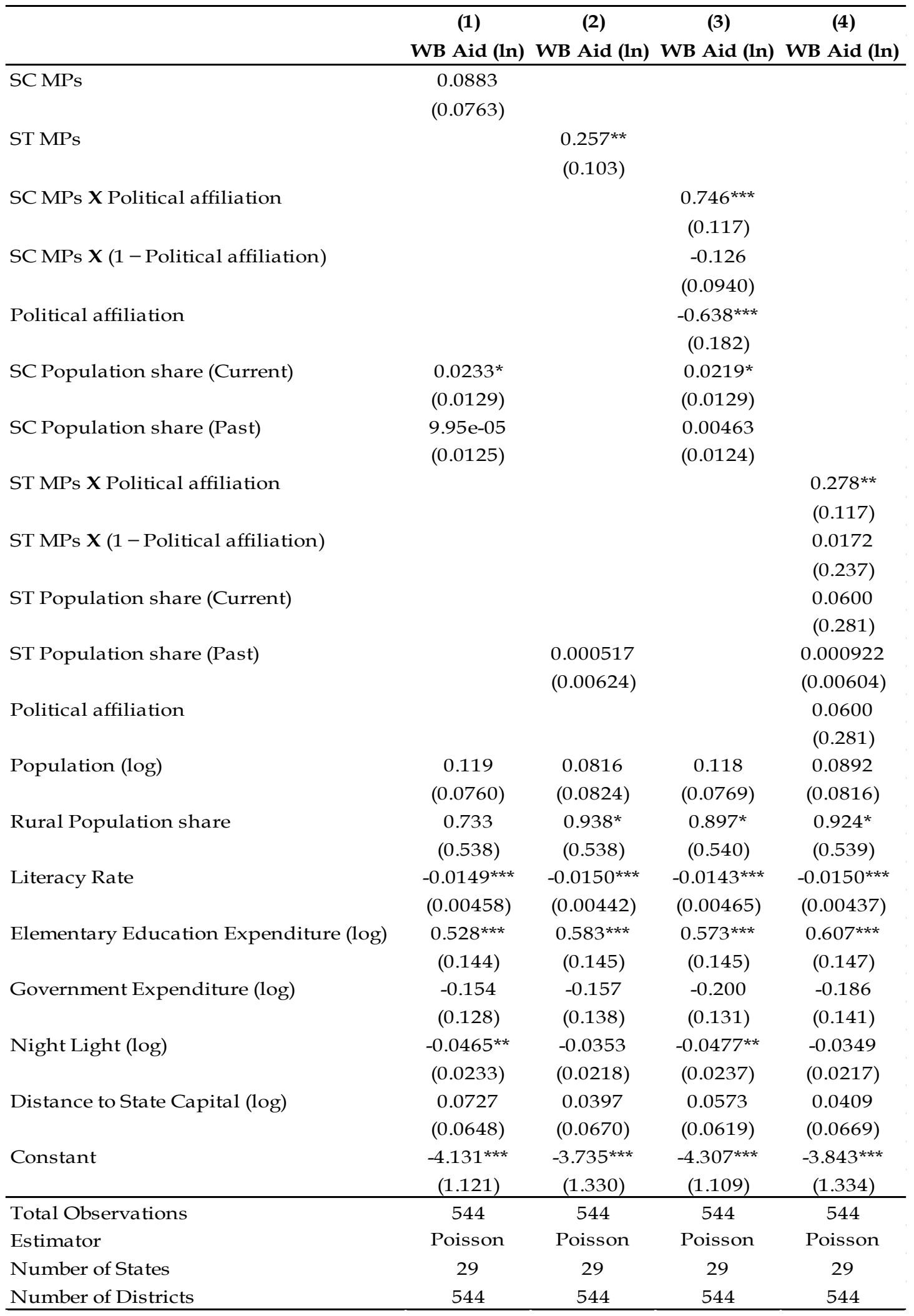

Notes: Robust standard errors in parenthesis

Statistical significance: ${ }^{* * *} p<0.01,{ }^{* *} p<0.05,{ }^{*} p<0.1$ 
Table E1: World Bank education aid and SC, ST MPs - Per capita measure

(1) (2) (3)

WB Aid PC (ln) WB Aid PC (ln) WB Aid PC (ln) WB Aid PC (ln)

\begin{tabular}{|c|c|c|c|c|}
\hline SC MPs & $\begin{array}{l}0.0540 \\
(0.224)\end{array}$ & & & \\
\hline ST MPs & & $\begin{array}{l}0.640^{* *} \\
(0.272)\end{array}$ & & \\
\hline SC MPs X Political affiliation & & & $\begin{array}{l}1.472^{* *} \\
(0.630)\end{array}$ & \\
\hline SC MPs X ( 1 - Political affiliation $)$ & & & $\begin{array}{l}-0.359 \\
(0.270)\end{array}$ & \\
\hline Political affiliation & & & $\begin{array}{l}-1.402 * \\
(0.765)\end{array}$ & \\
\hline SC Population share (Current) & $\begin{array}{c}0.0594^{* *} \\
(0.0292)\end{array}$ & & $\begin{array}{c}0.0590^{* *} \\
(0.0292)\end{array}$ & \\
\hline SC Population share (Past) & $\begin{array}{r}-0.00790 \\
(0.0277)\end{array}$ & & $\begin{array}{r}-0.00351 \\
(0.0274)\end{array}$ & \\
\hline ST MPs X Political affiliation & & & & $\begin{array}{c}1.086^{* * *} \\
(0.367)\end{array}$ \\
\hline ST MPs X (1 - Political affiliation) & & & & $\begin{array}{c}0.282 \\
(0.413)\end{array}$ \\
\hline Political affiliation & & & & $\begin{array}{l}-0.348 \\
(0.869)\end{array}$ \\
\hline ST Population share (Current) & & $\begin{array}{l}-0.0195 \\
(0.0121)\end{array}$ & & $\begin{array}{l}-0.0192 \\
(0.0120)\end{array}$ \\
\hline ST Population share (Past) & & $\begin{array}{l}0.00632 \\
(0.0113)\end{array}$ & & $\begin{array}{l}0.00684 \\
(0.0112)\end{array}$ \\
\hline Population (log) & $\begin{array}{l}-0.242 \\
(0.157)\end{array}$ & $\begin{array}{l}-0.304^{*} \\
(0.169)\end{array}$ & $\begin{array}{l}-0.239 \\
(0.158)\end{array}$ & $\begin{array}{l}-0.304^{*} \\
(0.168)\end{array}$ \\
\hline Rural Population share & $\begin{array}{c}0.961 \\
(0.920)\end{array}$ & $\begin{array}{c}1.414 \\
(0.901)\end{array}$ & $\begin{array}{c}1.135 \\
(0.909)\end{array}$ & $\begin{array}{c}1.370 \\
(0.903)\end{array}$ \\
\hline Literacy Rate & $\begin{array}{c}-0.0422^{* * *} \\
(0.00968)\end{array}$ & $\begin{array}{c}-0.0425^{* * *} \\
(0.00984)\end{array}$ & $\begin{array}{c}-0.0417^{* * *} \\
(0.00974)\end{array}$ & $\begin{array}{c}-0.0420^{* * *} \\
(0.00990)\end{array}$ \\
\hline Elementary Education Expenditure (log) & $\begin{array}{c}1.118^{* * *} \\
(0.252)\end{array}$ & $\begin{array}{c}1.083^{* * *} \\
(0.238)\end{array}$ & $\begin{array}{c}1.163^{* * *} \\
(0.250)\end{array}$ & $\begin{array}{c}1.104^{* * *} \\
(0.239)\end{array}$ \\
\hline Government Expenditure (log) & $\begin{array}{l}-0.340 \\
(0.290)\end{array}$ & $\begin{array}{l}-0.226 \\
(0.291)\end{array}$ & $\begin{array}{l}-0.403 \\
(0.290)\end{array}$ & $\begin{array}{l}-0.262 \\
(0.293)\end{array}$ \\
\hline Night Light (log) & $\begin{array}{l}-0.0457 \\
(0.0293)\end{array}$ & $\begin{array}{l}-0.0380 \\
(0.0284)\end{array}$ & $\begin{array}{l}-0.0441 \\
(0.0292)\end{array}$ & $\begin{array}{l}-0.0386 \\
(0.0286)\end{array}$ \\
\hline Distance to State Capital (log) & $\begin{array}{c}-0.0473 \\
(0.120)\end{array}$ & $\begin{array}{c}-0.0762 \\
(0.124)\end{array}$ & $\begin{array}{c}-0.0551 \\
(0.118)\end{array}$ & $\begin{array}{c}-0.0745 \\
(0.125)\end{array}$ \\
\hline Constant & $\begin{array}{l}-1.560 \\
(1.873) \\
\end{array}$ & $\begin{array}{l}-0.618 \\
(2.486) \\
\end{array}$ & $\begin{array}{l}-1.703 \\
(1.876) \\
\end{array}$ & $\begin{array}{l}-0.538 \\
(2.497) \\
\end{array}$ \\
\hline Total Observations & 542 & 542 & 542 & 542 \\
\hline Estimator & OLS & OLS & OLS & OLS \\
\hline Number of Districts & 542 & 542 & 542 & 542 \\
\hline R-squared & 0.235 & 0.220 & 0.242 & 0.221 \\
\hline
\end{tabular}

Notes: Robust standard errors in parenthesis

Statistical significance: ${ }^{* * *} p<0.01,{ }^{* *} p<0.05, * p<0.1$ 
Table F1: World Bank education aid and SC, ST MPs dropping statistically insignificant variables

\begin{tabular}{|c|c|c|c|c|}
\hline & (1) & (2) & (3) & (4) \\
\hline & WB Aid (ln) & WB Aid (ln) & WB Aid (ln) & WB Aid (ln) \\
\hline \multirow[t]{2}{*}{ SC MPs } & 0.996 & & & \\
\hline & $(0.790)$ & & & \\
\hline \multirow[t]{2}{*}{ ST MPs } & & $1.930^{* *}$ & & \\
\hline & & $(0.948)$ & & \\
\hline \multirow[t]{2}{*}{ SC MPs X Political affiliation } & & & $7.439^{* * *}$ & \\
\hline & & & $(0.991)$ & \\
\hline \multirow[t]{2}{*}{ SC MPs X (1 - Political affiliation) } & & & -0.616 & \\
\hline & & & $(1.061)$ & \\
\hline \multirow[t]{2}{*}{ Political affiliation } & & & $-6.524^{* * *}$ & \\
\hline & & & $(1.925)$ & \\
\hline \multirow[t]{2}{*}{ SC Population share (Current) } & $0.150^{*}$ & & $0.154^{*}$ & \\
\hline & $(0.0908)$ & & $(0.0906)$ & \\
\hline \multirow[t]{2}{*}{ SC Population share (Past) } & 0.0358 & & 0.0472 & \\
\hline & $(0.0874)$ & & $(0.0867)$ & \\
\hline \multirow[t]{2}{*}{ ST MPs X Political affiliation } & & & & $4.785^{* * *}$ \\
\hline & & & & $(1.346)$ \\
\hline \multirow[t]{2}{*}{ ST MPs X (1 - Political affiliation) } & & & & 0.990 \\
\hline & & & & $(1.497)$ \\
\hline \multirow[t]{2}{*}{ Political affiliation } & & & & -3.148 \\
\hline & & & & $(2.890)$ \\
\hline \multirow[t]{2}{*}{ ST Population share (Current) } & & $-0.0649^{*}$ & & $-0.0631^{*}$ \\
\hline & & $(0.0362)$ & & $(0.0364)$ \\
\hline \multirow[t]{2}{*}{ ST Population share (Past) } & & 0.0237 & & 0.0254 \\
\hline & & $(0.0373)$ & & $(0.0377)$ \\
\hline \multirow[t]{2}{*}{ Literacy Rate } & $-0.190^{* * *}$ & $-0.193^{* * *}$ & $-0.191^{* * *}$ & $-0.191^{* * *}$ \\
\hline & $(0.0301)$ & $(0.0304)$ & $(0.0301)$ & $(0.0310)$ \\
\hline \multirow[t]{2}{*}{ Elementary Education Expenditure (log) } & $2.209^{* * *}$ & $2.457^{* * *}$ & $2.180^{* * *}$ & $2.452^{* * *}$ \\
\hline & $(0.301)$ & $(0.341)$ & $(0.300)$ & $(0.345)$ \\
\hline \multirow[t]{2}{*}{ Night Light (log) } & $-0.132^{* * *}$ & $-0.139 * * *$ & $-0.136^{* * *}$ & $-0.139 * * *$ \\
\hline & $(0.0352)$ & $(0.0372)$ & $(0.0356)$ & $(0.0374)$ \\
\hline \multirow[t]{2}{*}{ Constant } & -4.589 & -3.561 & -4.312 & -3.642 \\
\hline & $(3.712)$ & $(4.725)$ & $(3.697)$ & $(4.725)$ \\
\hline Total Observations & 575 & 575 & 575 & 575 \\
\hline Estimator & OLS & OLS & OLS & OLS \\
\hline Number of Districts & 575 & 575 & 575 & 575 \\
\hline R-squared & 0.265 & 0.245 & 0.274 & 0.246 \\
\hline
\end{tabular}

Notes: Robust standard errors in parenthesis

Statistical significance: ${ }^{* * *} p<0.01,{ }^{* *} p<0.05,{ }^{*} p<0.1$ 